\title{
Review
}

\section{Therapeutic Applications of Programmable DNA Nanostructures}

\author{
Seaim Lwin Aye and Yusuke Sato * \\ Frontier Research Institute for Interdisciplinary Sciences, Tohoku University, Sendai 980-8578, Japan; \\ seaim.lwin.aye.c2@tohoku.ac.jp \\ * Correspondence: yusuke.sato.c8@tohoku.ac.jp
}

Citation: Aye, S.L.; Sato, Y.

Therapeutic Applications of

Programmable DNA Nanostructures.

Micromachines 2022, 13, 315. https://

doi.org/10.3390/mi13020315

Academic Editor: Nam-Trung

Nguyen

Received: 27 January 2022

Accepted: 16 February 2022

Published: 17 February 2022

Publisher's Note: MDPI stays neutral with regard to jurisdictional claims in published maps and institutional affiliations.

Copyright: (c) 2022 by the authors. Licensee MDPI, Basel, Switzerland. This article is an open access article distributed under the terms and conditions of the Creative Commons Attribution (CC BY) license (https:// creativecommons.org/licenses/by/ $4.0 /)$.

\begin{abstract}
Deoxyribonucleic acid (DNA) nanotechnology, a frontier in biomedical engineering, is an emerging field that has enabled the engineering of molecular-scale DNA materials with applications in biomedicine such as bioimaging, biodetection, and drug delivery over the past decades. The programmability of DNA nanostructures allows the precise engineering of DNA nanocarriers with controllable shapes, sizes, surface chemistries, and functions to deliver therapeutic and functional payloads to target cells with higher efficiency and enhanced specificity. Programmability and control over design also allow the creation of dynamic devices, such as DNA nanorobots, that can react to external stimuli and execute programmed tasks. This review focuses on the current findings and progress in the field, mainly on the employment of DNA nanostructures such as DNA origami nanorobots, DNA nanotubes, DNA tetrahedra, DNA boxes, and DNA nanoflowers in the biomedical field for therapeutic purposes. We will also discuss the fate of DNA nanostructures in living cells, the major obstacles to overcome, that is, the stability of DNA nanostructures in biomedical applications, and the opportunities for DNA nanostructure-based drug delivery in the future.
\end{abstract}

Keywords: DNA nanostructure; DNA nanorobots; DNA nanotechnology; drug delivery; cellular targeting; cell membrane; smart medicines; cancer therapy; gene therapy

\section{Introduction}

Advances in nanomedicine have led to the development of advanced therapeutic agents with new therapeutic functions, such as proteins, peptides, monoclonal antibodies, nucleic acids, and live cells. Drugs for precision medicine require solubility, stability, immunity, organ specificity, non-cytotoxicity, easy cellular uptake, and controlled release. Concurrently, new drug delivery strategies are needed to address these challenges by exploiting several technologies and methods, including physical methods, viral vectormediated delivery [1], and nanoparticle-mediated delivery [2]. Nanocarrier development for drug delivery and therapeutics applies nanoparticles (NPs) in organic forms, such as lipid-based nanoparticles (LNPs) [3-5], inorganic forms, such as gold nanoparticles (AuNPs) [6-8], polymeric nanoparticles, and polymer-lipid hybrid nanoparticles. A relatively recent strategy is the application of DNA-based nanostructures through DNA nanotechnology as controllable drug carriers and drug delivery systems. What sets DNA nanotechnology apart is that the technique offers nanoscale dimensions, programmability, biocompatibility, and the ability to functionalize DNA. This review focuses on drug delivery carriers and nanorobots for therapeutics based on self-assembled DNA nanostructures (DNSs) in terms of strategy, design, efficiency, and potential. DNSs, which are nanoscale structures made of sequence-designed DNAs, can be customized to program desired sizes and shapes for the desired applications including therapeutic ones.

DNA, the carrier of hereditary genetic information, can be used as a building block for synthesizing nanosized particles of desired shapes and sizes, owing to its unique chemical and structural properties. DNA nanotechnology employs DNA as a non-biological material for the self-assembly of nanoscale structures [9]. The first demonstration of a large-scale structure in 1998 involved the self-assembly of multiple oligonucleotides 
into nanoscale DNA tiles into higher-order periodic superstructures or DNA lattices of micrometer sizes [10]. Since then, such assemblies have been further constructed to form two- or three-dimensional structures of desired sizes, shapes, and conformations. In 2006, the invention of DNA origami further advanced DNA nanotechnology [11]. The strategy of creating DNA origami involves the application of a long single-stranded scaffold strand that can be folded into the desired structure by binding with many short single-stranded DNA oligonucleotides called staples. The size of the origami depends on the length of the scaffold, which can range from a few hundred nucleotides to several thousand nucleotides. This technique was further adopted and generalized for the self-assembly of the desired DNSs. With an intensive focus on DNA nanotechnology, it is of utmost importance to prove its potential applications with strong merits for practical applications. Aside from the obvious programmability of DNSs for accurate designs, it should also be demonstrated as a functional element in practical engineering devices. Potential applications can be set in programming biochemical pathways using logic gates, the design and implementation of sensing and computing nanodevices, and as tools for delivering therapeutic molecules to target cells with a controlled release.

\section{Fate of DNA Nanostructures in Living Cells}

\subsection{Targeted Drug Delivery}

One of the most important functions of a drug carrier is recognizing and attacking the target cells without interacting with healthy cells while simultaneously traveling through the body and maintaining structural integrity. Therefore, smart nanocarriers, such as nanorobots, must achieve targeted drug delivery or controlled drug release. As in the modification for cellular uptake, targeting a specific cell can be carried out by coupling delivery vehicles with ligands that bind to specific receptors commonly expressed at high levels in diseased cells. Depending on the targeted treatment, these ligands can be aptamers, antibodies, peptides, or other molecules. Aptamers [12], synthetic singlestranded DNA or RNA oligonucleotides, are capable of specific, high-affinity binding to a target that acts as a nucleic acid version of an antibody. Therefore, DNA aptamers can easily function as ligands for DNSs. For example, a DNA aptamer that can recognize a malaria protein biomarker has been combined with a rectangular DNA origami scaffold to serve as a malaria diagnostic material [13]. Peptides have been shown to enhance the efficacy of drugs while reducing toxicity to the cell [14]. Moreover, they can also be used for condensation to efficiently deliver DNA into cells by binding peptides onto the DNA chain through electrostatic interactions and self-associating into $\beta$-sheets through hydrophobic interactions and hydrogen bonding [15].

In cancer treatment, selective targeting of drugs to tumors is achieved by conjugating a drug to tumor-specific antibodies [16]. One study reported the rational design of a modular DNA-based nanomachine that can load and release its cargo upon binding to a specific antibody by using three different antigens, suggesting the potential application of such a design for controlled drug release [17]. Other receptors such as folate receptors can also be used to target tumors, for example, by coupling to a high-affinity ligand such as folic acid or by coupling to a monoclonal antibody against the receptor of interest [18]. One major advantage of DNS is its suitability for targeted delivery, owing to its highly programmable nature. This can be achieved by programming and determining a suitable size for the DNS by precisely controlling the spatial orientation of the targeting ligands on the structure of DNA. The modification scheme of DNS for therapeutic purposes via various cargo-loading strategies is shown in Figure 1. 


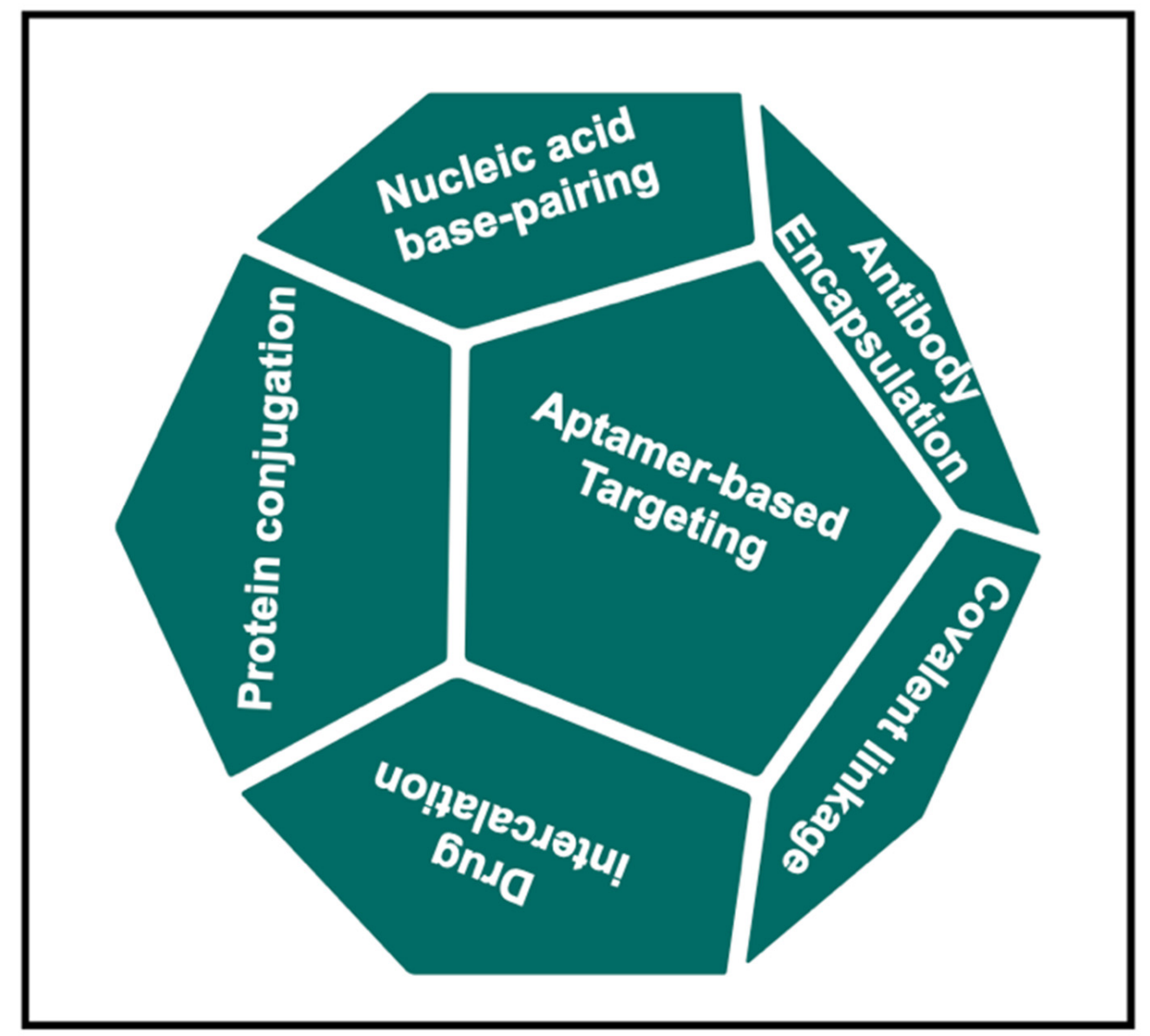

Figure 1. Scheme of self-assembled DNA nanocarriers for drug delivery using various cargoloading strategies.

\subsection{Cellular Uptake of DNA Nanostructures}

To improve the target specificity and cellular uptake of DNSs, structural modifications such as conjugation with a ligand or a transfection agent are usually required for mammalian cell internalization. For instance, DNA nanotubes have been conjugated with folate and Cy3 for cancer cell uptake [19]. With folate conjugation, DNA accumulation was observed at specific cellular locations and perinuclear regions; however, the mechanism of intracellular transportation is unknown. The uptake of DNS by cells can also be achieved through the action of DNA alone. For example, DNA tetrahedron cages have been shown to be taken up by human embryonic kidney (HEK) cells with or without a transfection agent [20]. In this case, the DNA tetrahedra were in the cytoplasm and remained intact within the cells for at least $48 \mathrm{~h}$ after transfection. However, the mechanism underlying this substantial uptake remains unknown. Hamblin et al. demonstrated increased cellular uptake by using DNA nanotubes produced via rolling circle amplification with increased uptake of double-stranded DNA into HeLa cells [21]. They suggested that a dense arrangement of a shell of DNA strands in core-shell structures can contribute to cellular uptake without the aid of a transfection agent, which has been similarly carried out before [22]. These findings uncovered the surprising factor that large and highly negatively charged DNSs can enter a cell even without conjugation with transfection agents; however, the mechanism of cellular uptake still remains elusive. Through endocytosis, particles less than $500 \mathrm{~nm}$ in size first bind to the plasma membrane and are internalized via receptormediated pathways [23]. Liang et al. reported the cellular entry, transport, and fate of tetrahedral DNA nanostructures (TDNs) as receptor-mediated endocytosis specifically mediated by caveolin [24]. They reported that internalized TDNs do not diffuse freely 
in the cytoplasm but are rather transported through microtubules, indicating that TDNs are transported in an ordered manner through molecular motors (kinesin and dynein) (Figure 2a) $[25,26]$. Confocal images of HeLa cells treated with TDNs over a period of time of 2-12 h, as well as flow cytometry analysis of cellular uptake, are shown in Figure 2b,c. They also reported that TDNs are eventually trapped within lysosomes, meaning that TDNs are recognized as foreign substances rather than as genetic material.
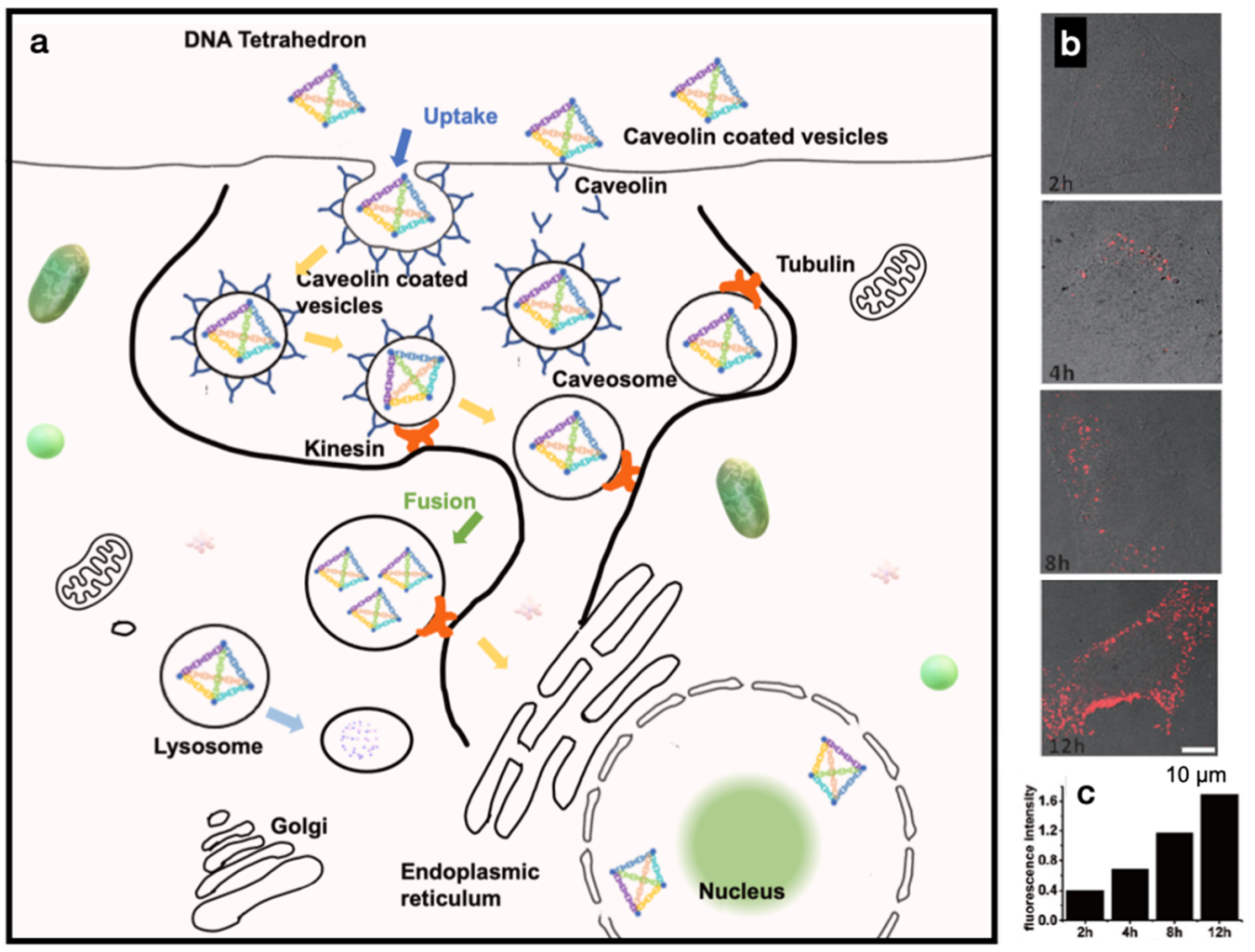

Figure 2. (a) Schematics of the cellular uptake, transport, and fate of TDNs. (b) Internalization of TDNs by HeLa cells treated with Cy3-conjugated TDNs for 2, 4, 8, and $12 \mathrm{~h}$. (c) Flow cytometry analysis of cellular uptake of Cy3-TDNs. Adapted with permission from [24] Copyright (C) 2022, WILEY-VCH Verlag GmbH \& Co. KGA, Weinheim.

It will be problematic to employ DNSs for therapeutic purposes if it results in lysosomal degradation. The size of caveolae vesicles ranging from 50 to $60 \mathrm{~nm}$ may only carry very small particles [27], limiting the pathway to DNSs of certain sizes. However, to overcome the lysosome degradation issue, Liang et al. further modified TDNs with signaling peptides to direct them to specific organelles such as the nucleus. This indicates that DNSs could be further modified to enhance cellular uptake or to direct them to the desired organelles. For example, coating rectangular DNA origami with virus capsid protein (CP) for transfection into HEK cells improved their delivery into cells by 13-fold compared to bare DNA origami [28]. One study mimicked the morphology of enveloped virus particles for design by encapsulating a DNA nano-octahedron inside a PEGylated lipid bilayer [29]. By enveloping DNSs in lipids, nuclease digestion was eliminated, immune activation was decreased, and bioavailability was increased 17-fold compared with the control. Coating DNSs with proteins such as BSA can also increase transfection into the human embryonic kidney while attenuating the activation of the immune response [30,31]. These findings suggest that coating DNA with DNA-binding proteins could provide a way to increase nanoscale rigidity while protecting it against enzymatic attack and elevated temperatures. DNA provides programmability, and proteins function as nanoscale structural rigidifiers. Moreover, compared to the design of DNSs that cross multiple DNA double helices in parallel to form stiff multi-helical bundles or sheets or using a scaffold for the organization 
of DNA strands, using hybrid protein-DNA complexes might be a simpler strategy. For a broader topic of building hybrid protein-DNA nanomaterials, we point to a review by Armando Hernadez-Garcia [32].

\subsection{Stability of DNA Nanostructures in Physiological Conditions}

The major challenge in the in vitro and in vivo applications of DNSs is the denaturation of DNSs with the depletion of divalent cations. Moreover, fetal bovine serum (FBS), the cell culture medium used in cells in vitro, contains nucleases that can potentially result in the digestion of DNA. To address this issue, Hahn et al. [33] focused on determining the stability of DNA using in vitro tissue cultures to prototype DNA nanorobots. They tested three different structures: a DNA nano-octahedron $(45 \mathrm{~nm})$, a six-helix bundle nanotube $(400 \mathrm{~nm})$, and a 24-helix nanorod $(16 \times 89 \mathrm{~nm})$ with different concentrations of $\mathrm{Mg}^{2+}$. They reported that the sensitivity of nanostructures to divalent cation depletion depends on their design and duration of treatment. Among the tested structures, only one (DNA nanotube) was stable and remained intact after $24 \mathrm{~h}$ at $37^{\circ} \mathrm{C}$. The addition of $\mathrm{MgSO}_{4}$ with an equivalent dilution to prevent osmotic shock provided a viable option for maintaining DNS integrity. While FBS is stored at $4{ }^{\circ} \mathrm{C}$, the level of nuclease activity disappears over days to weeks; hence, it is only a concern for a short period following the preparation medium. In total, $1-2.5 \%$ of FBS had little capacity to digest DNA at a $5 \mathrm{nM}$ concentration over $24 \mathrm{~h}$. Therefore, low serum concentration could be used instead of a short incubation time with FBS.

Keum et al. tested the resistance of DNSs to DNase I by comparing digestion patterns between TDNs and linear DNA structures [34]. In their study, TDNs were found to be up to three times more resistant than double-stranded DNA. Different nuclease digestions of DNA origami showed that the degradation rate of DNase I was several hundred-fold slower than that of duplex DNA, suggesting that DNA origami is more stable than smaller TDNs. DNSs can withstand degradation by nucleases better than simple linear DNA, probably because of their interconnected and compact structural design. Mei et al. tested the fate of DNA origami in a rectangular shape $(90 \mathrm{~nm} \times 60 \mathrm{~nm})$, a 2D equilateral triangular structure $(120 \mathrm{~nm} \times 30 \mathrm{~nm})$, and a 3D multilayer rectangular structure (8-helix $\times 8$-helix square lattice with dimensions of $16 \mathrm{~nm} \times 16 \mathrm{~nm} \times 30 \mathrm{~nm}$ ) in cell lysates from normal and cancerous cell lines [35]. Their results demonstrated that, in contrast to natural, single- and double-stranded DNA, DNA origami nanostructures (DONs) could be easily separated from lysate mixtures and are fully intact after separation. In this case, the robustness of the DNA origami might be due to the presence of a higher concentration of $\mathrm{Mg}^{2+}$ in the assembly process than what might be expected in the cell.

Most of the time, the physiological temperature of $37^{\circ} \mathrm{C}$ is used for biological operations; hence, the stability of DNSs at $37^{\circ} \mathrm{C}$ for multiple hours should be adequate, depending on the application. According to these findings, the resistance of DNSs to nucleases is related to their structural design. The more compact the structure, the more it can tolerate the attack of nucleases than linear DNA. However, the size of DNSs and their complexity should be considered because a complex design might negatively contribute to cellular uptake and cell biocompatibility. In terms of low or high concentrations of divalent cations, there should be a compromise between the amount required for the structural integrity of DNA and the amount normally present in the body. Several attempts and modifications have been made to overcome nuclease degradation (Table 1). Most experiments used culture media to test in vitro and ex vivo conditions. Such results may not be entirely adaptable in vivo given different physiological conditions in the human body, such as temperature, enzymatic presence, immune response, among others. 
Table 1. Strategies to modulate nuclease resistance in a living cell.

\begin{tabular}{|c|c|c|c|c|c|c|}
\hline \multirow{2}{*}{ Structure } & \multirow{2}{*}{ Size (nm) } & \multirow{2}{*}{ Strategy } & \multirow{2}{*}{ Test } & \multicolumn{2}{|c|}{ Results } & \multirow{2}{*}{ Ref. } \\
\hline & & & & Before Modification & After Modification & \\
\hline 24-HB & 100 & $\begin{array}{l}\text { Close-packed } \\
\text { helices }\end{array}$ & DNase I & $\begin{array}{l}\text { Duplex plasmid DNA } \\
\text { degraded in } 5 \mathrm{~min}\end{array}$ & $\begin{array}{l}\text { Close-pack helices } \\
\text { degraded in } 1 \mathrm{~h}\end{array}$ & {$[36]$} \\
\hline Tweezers & 14 & Topology & $70 \%$ human serum & Open state in $20 \mathrm{~h}$ & Closed state in $37 \mathrm{~h}$ & {$[37]$} \\
\hline $\begin{array}{c}\text { Paranemic } \\
\text { crossover (PX), } \\
\text { Double crossover } \\
\text { (DX), Duplex } \\
\text { DNA }\end{array}$ & 13 & $\begin{array}{l}\text { Increased } \\
\text { crossovers }\end{array}$ & $\begin{array}{l}\text { 10\% FBS, human } \\
\text { serum and urine, } \\
\text { DNase I, } \\
\text { Exonuclease V, } \\
\text { T5 and T } 7\end{array}$ & & $\begin{array}{l}\text { PX-not degraded } \\
\text { DX-not degraded } \\
\text { Duplex-degraded }\end{array}$ & {$[38]$} \\
\hline Octahedron & 50 & Heating FBS & Media $+10 \%$ FBS & $\begin{array}{c}0 \% \text { intact } \\
\text { without heating }\end{array}$ & $\begin{array}{l}100 \% \text { intact with } \\
\text { heating }\end{array}$ & [33] \\
\hline $\begin{array}{l}\text { Octahedron } \\
\text { Nanotube } \\
\text { Nanorod }\end{array}$ & $\begin{array}{c}50 \\
400 \\
89\end{array}$ & $\begin{array}{l}\text { Nuclease } \\
\text { inhibitors }\end{array}$ & Media $+10 \%$ FBS & $0 \%$ intact without acting & $\begin{array}{l}100 \% \text { intact } \\
\text { with actin }\end{array}$ & {$[33]$} \\
\hline Tetrahedron & 14 & $\begin{array}{l}\text { Ethylenediamine } \\
\text { buffer }\end{array}$ & DNase I & $\begin{array}{l}0 \% \text { intact in TAE } \\
\text { with } \mathrm{Mg}^{2+} \text { buffer }\end{array}$ & $\begin{array}{l}100 \% \text { intact in } \\
\text { ethylenediamine } \\
\text { buffer }\end{array}$ & [39] \\
\hline Nanotube & 30 & $\begin{array}{l}\text { Crosslinking } \\
\text { (Click chemistry) }\end{array}$ & Exonuclease & Fully degraded & $\begin{array}{l}\text { Partially degraded } \\
\text { for crosslinked }\end{array}$ & {$[40]$} \\
\hline $\begin{array}{l}\text { Brick-like DNA } \\
\text { origami }\end{array}$ & 70 & $\begin{array}{c}\text { Crosslinking } \\
\text { (UV-induced T-T } \\
\text { dimers) }\end{array}$ & DNase I & $10 \mathrm{~min}$ & $1 \mathrm{~h}$ & {$[41,42]$} \\
\hline $\begin{array}{l}\text { Triangular prism, } \\
\text { tetrahedron }\end{array}$ & 7 & $\begin{array}{l}\text { Hexanediol and } \\
\text { hexamethylene } \\
\text { glycol }\end{array}$ & Media $+10 \%$ FBS & $18 \mathrm{~h}$ lifetime & 55 h lifetime & {$[43,44]$} \\
\hline DNA brick & 50 & $\begin{array}{c}\text { Dendritic } \\
\text { oligonucleotides }\end{array}$ & $\begin{array}{c}\text { DNase I } \\
(100 \mathrm{U} / \mathrm{mL})\end{array}$ & $\begin{array}{l}\text { Fully degraded } \\
\text { with } 5 \mathrm{U} / \mathrm{mL}\end{array}$ & $\begin{array}{c}\text { Coated- } \\
50 \% \text { degraded } \\
\text { with } 100 \mathrm{U} / \mathrm{mL}\end{array}$ & {$[45]$} \\
\hline Origami rod & 350 & $\begin{array}{c}\text { Cationic } \\
\text { polysaccharides }\end{array}$ & DNase I & Stable for $1 \mathrm{~h}$ & Stable for $24 \mathrm{~h}$ & {$[46]$} \\
\hline Origami barrel & 60 & $\begin{array}{l}\text { Oligolysine-PEG } \\
\text { copolymer }\end{array}$ & Media $+10 \%$ FBS & 5 min half-life & 50 min half-life & [47] \\
\hline Octahedron & 76 & $\begin{array}{l}\text { PEGylated lipid } \\
\text { bilayer }\end{array}$ & DNase I & $30 \%$ intact & $85 \%$ intact & [29] \\
\hline $60 \mathrm{HB}$ & $\begin{array}{c}20 \times \\
20 \times \\
33\end{array}$ & $\begin{array}{l}\text { BSA-dendron } \\
\text { conjugates }\end{array}$ & Media $+10 \%$ FBS & $20 \%$ intact & $100 \%$ intact & {$[31]$} \\
\hline $24 \mathrm{HB}$ & 100 & Silica coating & DNase I & Completely degraded & Almost fully intact & [48] \\
\hline Octahedron & 29 & Peptides & DNase I & Completely degraded & Almost fully intact & {$[48]$} \\
\hline $\begin{array}{l}\text { 4-Arm junction } \\
\text { Nanotube }\end{array}$ & $\begin{array}{c}5 \\
30-70\end{array}$ & $\begin{array}{l}\text { L-DNA (mirror } \\
\text { form of D-DNA) }\end{array}$ & $\begin{array}{c}\text { Exonuclease I } \\
\text { Exonuclease III }\end{array}$ & Completely degraded & Almost fully intact & {$[42]$} \\
\hline
\end{tabular}

\section{Molecular Payloads}

A collection of multiple DNA structures and designs for published drug delivery systems is shown in Figure 3. All the included studies have the same underlying principle and purpose of delivering the payload effectively with enhanced efficiency while protecting it from degradation by external factors during transport. The payload choice depends on the type of targeted disease, the outcome of the therapeutic effect, and the ability of the payload to integrate into the DNSs. The categories of payloads include (i) small molecules such as DOX, (ii) nucleic acids, aptamers and ligands, DNAs and RNAs, (iii) proteins and peptides, and (iv) other molecules such as metals and biotins. Here, we will discuss the payloads that can be categorized as biocompatible and therapeutic agents in more detail. DNSs specifically targeted for application in cancer therapy are listed in Table 2. While most of the studies included are still in the in vitro, ex vivo, or animal model stage, TDN 
was found to be the most commonly used DNS and DOX as the commonly used drug. Most structures are conjugated with ligands and receptors, such as aptamers and folate, to improve specificity and cellular uptake.

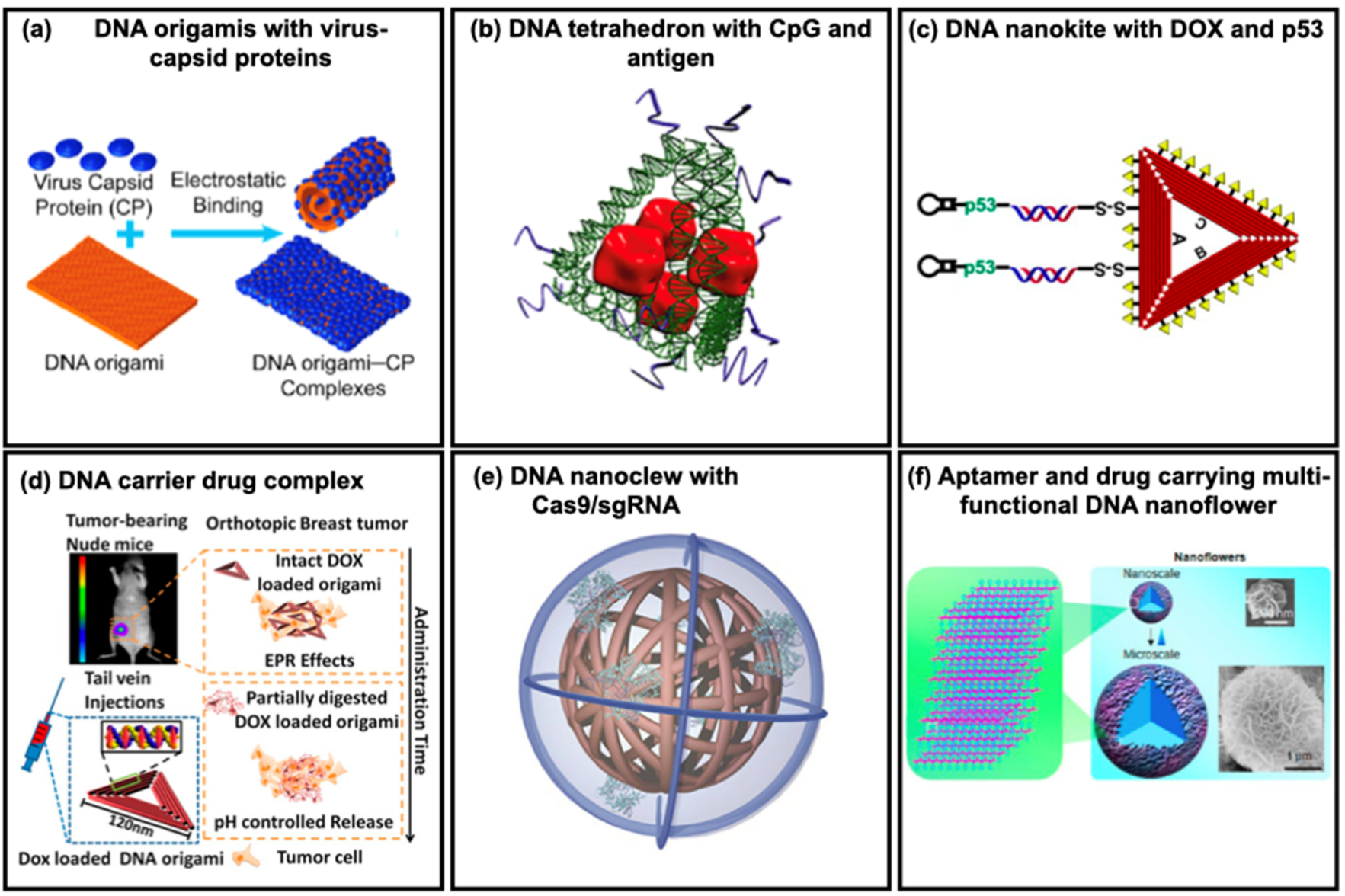

Figure 3. Drug delivery systems based on DNA nanostructures. (a) Self-assembly of DNA origami with virus capsid proteins (CPs) to increase transfection efficiency to the cell. Adapted with permission from [28]. Copyright (C 2022, American Chemical Society. (b) Tetrahedral DNA nanostructure with $\mathrm{CpG}$ and antigen as a synthetic vaccine complex. Adapted with permission from [49]. Copyright (C) 2022, American Chemical Society. (c) A DNA nanostructure-based co-delivery system containing a linear tumor therapeutic gene (p53) and a chemotherapeutic drug (doxorubicin, DOX) for the combined therapy of multidrug-resistant tumors (MCF-7R). Adapted with permission from [50]. Copyright (C) 2022, American Chemical Society. (d) DOX/DNA origami complexes injected into the tail of tumor-bearing mice was delivered through blood circulation to accumulate in the breast tumor of mice due to enhanced permeability and retention (EPR) effects. Adapted with permission from [51]. Copyright (C) 2022, American Chemical Society. (e) Yarn-like DNA nanoparticles synthesized via rolling circle amplification for the delivery of a CRISPR system (Cas9/single guide RNA complex). Adapted with permission from [52]. Copyright (C 2022, WILEY-VCH Verlag GmbH \& Co. KGA, Weinheim. (f) Multifunctional DNA NF generated by rolling circle replication can be integrated with aptamer and drug. The diameters of NFs range from $\sim 200 \mathrm{~nm}$ to several micrometers. Adapted with permission from [53]. Copyright (C) 2022, American Chemical Society.

\subsection{Doxorubicin}

DNSs have largely been applied as carrier systems to deliver DOX, a potent anti-cancer drug used to treat a wide range of cancers. DOX can non-covalently bind to double-stranded DNA through intercalation into the helix and is attributed to the convenience of using DNSs for DOX delivery to cancer cells [54]. Jiang et al. independently applied DNA origami structures to deliver DOX into MCF7 cells, a human breast adenocarcinoma cancer cell 
line [55]. They applied Watson-Crick base pairs in double helices as docking sites for DOX intercalation. Via confocal fluorescence microscopy analyses, the internalization of DOX-origami structures and the co-localization signals from both the drug and carrier were found in the cytoplasm after $24 \mathrm{~h}$ of treatment. Both free and origami-coupled drugs effectively induced cell death in a regular cell line. The free drug and drug-loaded dsDNA could not kill drug-resistant MCF7 cells, whereas the origami-bound drug caused cancer cell death, indicating that the carrier-coupled drug can overcome drug resistance. Drugs with DNSs can enhance their cellular uptake, thereby overcoming their decreased cell internalization, leading to the circumvention of drug resistance. Theoretically, the release of loaded drugs can be achieved through the slow degradation of DNSs by low environmental $\mathrm{pH}$ or DNA-degrading enzymes, contributing to the potential for controlled drug release.

Similarly, via drug-DNA intercalation, another attempt at DOX delivery into three different breast cancer cell lines was performed using two different DONs of 18-helix bundle nanotubes which are a straight nanotube (10.5 bp per turn) and a twisted nanotube (12 bp per turn) [56]. The structures were designed with varying degrees of global twists to achieve different degrees of relaxation in the DNA double-helix structure. Compared to free DOX, the twisted nanotube structure performed better in encapsulation efficiency and drug release rate, increased cytotoxicity, and decreased intracellular elimination rate. An L-DNA tetrahedron nanostructure (L-TDN), where $\mathrm{L}$ is the mirror form of the naturally occurring D-DNA, was used to deliver DOX into cancer cells in vitro and tumor-bearing mice in vivo with previous findings of higher cell penetration than D-TDN [57]. Between L-TDN molecules of two different sizes, one with 17-mer per side and another with 30-mer per side, they found that smaller L-TDNs can enhance drug accumulation in tumors at low doses compared to larger ones.

While DNSs undoubtedly function as DOX carriers, their functionality can be enhanced via modification with an aptamer that can bind to overexpressed molecules on certain cell surfaces to improve specificity and enhance cellular uptake. By modifying TDNDOX with the aptamer sgc8c, a short DNA sequence that can target protein tyrosine kinase 7, one study delivered DOX to PTK7-positive human T cells CCRF-CEM [58]. They suggested that PTK1-positive CCRF-CEM cells were more cytotoxic than PTK7-negative Ramos cells upon treatment with the sgc8c-TDN:DOX complex. Another use of DNA origami as a DOX carrier was tested with three different origami shapes, a triangle $(120 \mathrm{~nm})$, a square $(90 \mathrm{~nm} \times 90 \mathrm{~nm})$, and a tube $(380 \mathrm{~nm})$. These origami-drug complexes were injected into tumor-bearing mice [51]. Through in vivo and ex vivo imaging, they indicated that DNA origami possesses enhanced tumor targeting and long-lasting accumulation in the tumor region. Among the three structures, the triangle-shaped DNA origami showed optimal accumulation, where the signal mostly remained in the tumor. The square and tube-shaped DNA origami were primarily distributed in the tumor, liver, and kidneys.

Similar to aptamers, folic acid can be used to modify TDN carriers. In one study, DOX intercalation with TDNs was coupled with folic acid to target HT-29 colon cancer cells expressing folate receptors [59]. This strategy increased the cellular uptake of the drug in the presence of folic acid-DNA:DOX compared to that without folic acid, suggesting facilitated penetration through the membrane. The SL2B aptamer, which can inhibit cancer cell growth by disturbing the vascular endothelial growth factor (VEGF) signaling pathways, was used as an additional modification to the TDN to target colorectal cancer [60]. In this design, the TDN was modified with folate and SL2B. Upon encountering the cell, SL2B binds to VEGF165 and inhibits cancer cells growth by interfering with VEGF signaling pathways. Folate-receptor interactions can enhance the cellular uptake and subsequent delivery of DNSs via receptor-mediated endocytosis. Such a combination of nucleic acids and chemotherapy, along with receptor-mediated enhanced cellular uptake, drastically increased the intracellular concentration of DOX over a thousand-fold more than free DOX. Different $F$ and SL2B modifications resulted in varied cell inhibition, where TDN-DOX-2F2S showed significantly higher HT-29 cell inhibition than free DOX, TDN-DOX-2F, or TDN- 
DOX-FS. TDN-DOX-S also induced more cell death than TDN-S, indicating a synergistic effect between the aptamer and the drug.

Another use of aptamers was reported in a DNA nanocentipede (DNC), where the long trunk was loaded with DOX and the legs were SMMC-7721 cell-binding aptamers (Zy1) that can target cells more firmly and selectively [61]. Flow cytometric analyses demonstrated that Zy1 with DNC was more effective in terms of binding affinity and selectivity than free Zy-1. Multidrug resistance (MDR) protects a tumor cell against several drugs with different chemical structures and mechanisms of action [62]. Mei et al. applied a DNA nanoflower (DNF) with a tunable size of up to $200 \mathrm{~nm}$ in diameter to deliver DOX to MDR cancer cells and chemosensitive cells [63]. NFs can self-assemble via the liquid crystallization of DNA generated through rolling circle replication, during which aptamers, fluorophores, and DOX are incorporated. DOX-loaded NFs were found to be stable at physiological $\mathrm{pH}$, and drug release was facilitated by either acidic or basic conditions. They reported that NFs delivered DOX into chemosensitive and MDR cells, inducing potent cytotoxicity, while non-target cells were left unharmed. Kim et al. previously demonstrated the targeting of MDR using a DNA tetrahedron for the delivery of DOX into drug-resistant breast cancer cells [64]. Interestingly, Liu et al. combined chemotherapy with gene therapy by co-delivering DOX with a linear tumor therapeutic gene (p53) and a DNA origami targeting a multidrug-resistant tumor (MCF-7R) [50]. The design resembles a kite (a nanokite) where DOX is intercalated within the triangular space of a triangular origami with a protruding disulfide linker hybridized with p53. The images of excised tumors from mice after 24 days of treatment showed a drastic decrease in the size of tumors treated with DOX and p53 compared to DOX without the p53 sequence and vice versa. Their findings suggest that such a coupled therapy can not only overcome drug resistance but also demonstrate the potential of DNS as a carrier for gene therapeutics.

The above-mentioned findings support the application of DNSs for enhanced drug internalization and the circumvention of drug resistance using a relatively convenient strategy such as click chemistry. By combining chemotherapy and gene therapy (Figure 4), the potential of DNS-based smart therapeutics is increasing as more modifications with ligands for target specificity and enhanced uptake are discovered, while maintaining carrier biocompatibility. However, each approach has a different loading strategy, $\mathrm{pH}$, working environment, and DOX concentration, making it difficult to interpret and compare the results of such findings. Moreover, high concentrations of DOX during the loading process can also lead to the self-aggregation of DOX. Another important factor is the hybridization ability of DOX with self-hybridized staples if excess staples are not eliminated after the folding process. In addition to DOX, another intercalating drug, daunorubicin, a chemotherapeutic agent used to treat leukemia, can be loaded into DNSs. Halley and colleagues employed rod-like horse DNSs to circumvent daunorubicin drug resistance in the leukemia cell line HL-60/ADR with enhanced drug efficacy [65]. They hypothesized that the free drug delivered in solution enters cells via passive diffusion and that the horse nanostructures enter cells via endocytosis. This process leads to larger amounts of the drug in the cell, enhancing drug efficiency while maintaining a clinically relevant concentration of daunorubicin $\left(0.1-1.0 \times 10^{-6} \mathrm{M}\right)$.

Table 2. DNA nanostructures in cancer therapy.

\begin{tabular}{cccc}
\hline Structure & Payload & Modification & Results \\
\hline TDN & DOX & Folate receptor & 6h incubation induced apoptosis of HT 29 colon \\
cancer cells.
\end{tabular}


Table 2. Cont.

\begin{tabular}{|c|c|c|c|c|}
\hline Structure & Payload & Modification & Results & Ref. \\
\hline TDN & DOX & Folate receptor & $\begin{array}{l}\text { A synergic anti-cancer biological effect } \\
\text { with chemotherapy. }\end{array}$ & [59] \\
\hline $\mathrm{TDN}$ & 5-FU & AS1411 aptamer & Better targeting ability to kill breast cancer. & [68] \\
\hline TDN & DOX & AS1411 + MUC1 aptamer & $\begin{array}{l}\text { Lower cytotoxicity to MUC1-negative cells, equal } \\
\text { lethality to sensitive cells, and more effective to } \\
\text { DOX resistant cells. }\end{array}$ & [69] \\
\hline TDN & $\mathrm{TMZ}$ & AS1411 + GS24 & $\begin{array}{l}\text { Attenuate drug resistance in temozolomide } \\
\text { (TMZ)-resistant cells with specific binding to } \\
\text { transferrin receptor. }\end{array}$ & [70] \\
\hline $\mathrm{TDN}$ & Ir & AS1411 + MUC1 aptamer & Inhibits the growth and invasion of glioma cells. & [71] \\
\hline TDN & ASOs & $\begin{array}{l}\text { Nuclear localization } \\
\text { peptide }\end{array}$ & $\begin{array}{l}\text { Antisense strands released inhibit cell } \\
\text { proliferation at a low concentration without } \\
\text { transfection reagent with efficient knockdown of } \\
\text { the } c \text {-raf gene. }\end{array}$ & [72] \\
\hline TDN & DOX & & $\begin{array}{l}\text { Efficient delivery of DOX into drug-resistant } \\
\text { breast cancer cells. }\end{array}$ & [64] \\
\hline TDN & DOX & KLA peptide & $\begin{array}{l}\text { 3KLA-modified TDNs designed for } \\
\text { mitochondrial targeting exhibited the most } \\
\text { efficient DOX accumulation in mitochondria of } \\
4 \mathrm{~T} 1 \text { cells leading to an effective release of } \\
\text { cytochrome c, and the upregulated expression } \\
\text { levels of caspase-9, caspase-3, p21, and p53. }\end{array}$ & [73] \\
\hline NF & DOX & & $\begin{array}{l}\text { Circumvent drug-resistant cells with less side } \\
\text { effects to non-target cells. }\end{array}$ & [63] \\
\hline NF & DOX & $\operatorname{Sgc} 8$ & $\begin{array}{l}\text { Preparation of multifunctional DNA } \\
\text { Nanoflowers that are resistant to nuclease and } \\
\text { can integrate with different functional moieties. }\end{array}$ & [74] \\
\hline DNA triangle & DOX & & $\begin{array}{c}\text { Exhibited remarkable anti-tumor efficacy without } \\
\text { systemic toxicity in mice with orthotopic } \\
\text { breast tumors. }\end{array}$ & [51] \\
\hline DNA triangle & BMEPC & & $\begin{array}{l}\text { Cellular-level dual-functional imaging and } \\
\text { photodynamic therapy that generates free } \\
\text { radicals and subsequent apoptosis. }\end{array}$ & [75] \\
\hline $\begin{array}{l}\text { DNA triangle and } \\
\text { tube }\end{array}$ & DOX & & $\begin{array}{l}\text { Increased cellular internalization of DOX with } \\
\text { enhanced cell-killing activity to drug-resistant } \\
\text { adenocarcinoma cells. }\end{array}$ & [55] \\
\hline $\begin{array}{l}\text { DNA tube with } \\
\text { conformational } \\
\text { change to DNA } \\
\text { sheet }\end{array}$ & Thrombin & AS1411 aptamer & $\begin{array}{l}\text { Nucleolin-targeting aptamer serves both as a } \\
\text { targeting domain and as a molecular trigger for } \\
\text { the mechanical opening of DNA nanorobot } \\
\text { delivering thrombin, specifically } \\
\text { tumor-associated blood vessels, and inducing } \\
\text { intravascular thrombosis resulting in tumor } \\
\text { necrosis and inhibition of tumor growth. }\end{array}$ & [76] \\
\hline DNA icosahedron & DOX & MUC1 aptamer & $\begin{array}{l}\text { DOX@Apt-DNA-icosa shows efficient and } \\
\text { specific internalization for killing epithelial } \\
\text { cancer cells. }\end{array}$ & [77] \\
\hline DNA dendrimer & EPI & AS1411+ MUC1 aptamer & $\begin{array}{l}\text { Apts-Dendrimer-Epi complex released Epi in a } \\
\text { pH-sensitive manner (more release at pH 5.5), } \\
\text { prohibiting tumor growth in vitro and in vivo. }\end{array}$ & [78] \\
\hline
\end{tabular}


Table 2. Cont.

\begin{tabular}{|c|c|c|c|c|}
\hline Structure & Payload & Modification & Results & Ref. \\
\hline DNA nanorod & Daunorub-icin & & $\begin{array}{c}\text { Circumvent efflux pump-mediated drug } \\
\text { resistance in leukemia cells at clinically relevant } \\
\text { drug concentrations. }\end{array}$ & [65] \\
\hline DNA nanocircuit & Chlorin e6 & Aptamer & $\begin{array}{l}\text { Aptamer-based DNA nanocircuit selectively } \\
\text { recognizes target cancer cells, activates } \\
\text { photosensitizers, and amplifies the } \\
\text { photodynamic therapeutic effect. }\end{array}$ & [79] \\
\hline DNA nanotrain & DOX & AS1411, Sgc8 & $\begin{array}{l}\text { Locomotives guiding nanotrains with boxcars } \\
\text { carrying high payload allowing } \\
\text { intracellular signaling. }\end{array}$ & [80] \\
\hline $\begin{array}{c}\text { DNA } \\
\text { nanocentipede }\end{array}$ & DOX & Zy1 & $\begin{array}{l}\text { Effective binding affinity and selectivity with } \\
\text { enhanced cellular cytotoxicity to the target cell } \\
\text { but not to negative control cells. }\end{array}$ & [61] \\
\hline X-Y-Shaped DNA & DOX & Sgc8 & $\begin{array}{l}\text { Specific cytotoxic effect against leukemia cells } \\
\text { with the incorporation of therapeutic antisense } \\
\text { oligonucleotides inhibiting efflux pump of drug } \\
\text { circumventing drug resistance. }\end{array}$ & [81] \\
\hline $\begin{array}{l}\text { Biotinylated } \\
\text { octahedral DNA } \\
\text { nanocages }\end{array}$ & DOX & Folic acid & $\begin{array}{l}\text { DOX-loaded Bio-Fol-DNA nanocages delivered } \\
\text { DOX selectively to the folate receptor-enriched } \\
\text { Hela cells. }\end{array}$ & [82] \\
\hline $\begin{array}{l}\text { A 3D tubular } \\
\text { DNA origami } \\
\text { with six helical } \\
\text { bundles }\end{array}$ & DOX & $\begin{array}{c}\text { DUPA (a small } \\
\text { molecule ligand) }\end{array}$ & $\begin{array}{l}\text { Ligand conjugate DONs delivered DOX with } \\
\text { high affinity and selectivity into the } \\
\text { prostate-specific membrane antigen (PSMA)+ } \\
\text { cancer cell line LNCaP. DOX-DUPA-DONs } \\
\text { showed lower toxicity against PC-3 cells (PSMA-) } \\
\text { in comparison to free DOX. }\end{array}$ & [83] \\
\hline $\begin{array}{l}\text { tFNA (Tetral } \\
\text { framework } \\
\text { nucleic acid) }\end{array}$ & $\begin{array}{l}\text { Maytansin-e } \\
\text { (DM1) }\end{array}$ & HApt-aptamer & $\begin{array}{l}\text { HApt-tFNA@DM1 (HApDC) could target HER2 } \\
\text { protein and delivered chemotherapeutic agents } \\
\text { into HER2-positive breast tumor. HApDCs } \\
\text { exerted enhanced anti-tumor efficiency in } \\
\text { comparison with free drug and synthetic } \\
\text { liposome-derived vesicles without side effects. }\end{array}$ & [84] \\
\hline $\begin{array}{c}\text { All-sealed } \\
\text { divalent aptamer } \\
\text { Tetrahedral DNA } \\
\text { framework } \\
\text { (asdTDF) }\end{array}$ & $\begin{array}{c}\text { Therapeutic } \\
\text { protein }\end{array}$ & Aptamer & $\begin{array}{l}\text { The ligase-assisted seal of the nicks resulted in } \\
\text { the enhanced TDF stability against nuclease } \\
\text { digestion protecting the therapeutic protein from } \\
\text { degradation. Endogenous gluathione can trigger } \\
\text { the release of therapeutic protein leading to the } \\
\text { apoptosis of the specific cancer cells. }\end{array}$ & [85] \\
\hline Tetrahedral DNA & $\begin{array}{l}\text { Photother-anostic } \\
\text { molecule (IR780) }\end{array}$ & & $\begin{array}{l}\text { The in vitro and ex vivo photothermal and } \\
\text { photodynamic efficiencies of IR780 in the tumor } \\
\text { site was high in IR780@Td with enhanced tumor } \\
\text { imaging and anti-tumor effects than IR780 alone. }\end{array}$ & [86] \\
\hline $\begin{array}{l}\text { A triplex-DNA } \\
\text { nanoswitch }\end{array}$ & $\begin{array}{l}\text { Drug combo } \\
\text { (Antisense DNA, } \\
\text { Cisplatin, DOX }\end{array}$ & Aptamer & $\begin{array}{l}\text { The effects of gene silencing and significant } \\
\text { inhibition of tumor growth was shown with } \\
\text { tumor-bearing mouse models upon intravenous } \\
\text { administration of smart pH responsive } \\
\text { nanoswitch that can be used for combinatorial } \\
\text { cancer therapy. }\end{array}$ & [87] \\
\hline
\end{tabular}




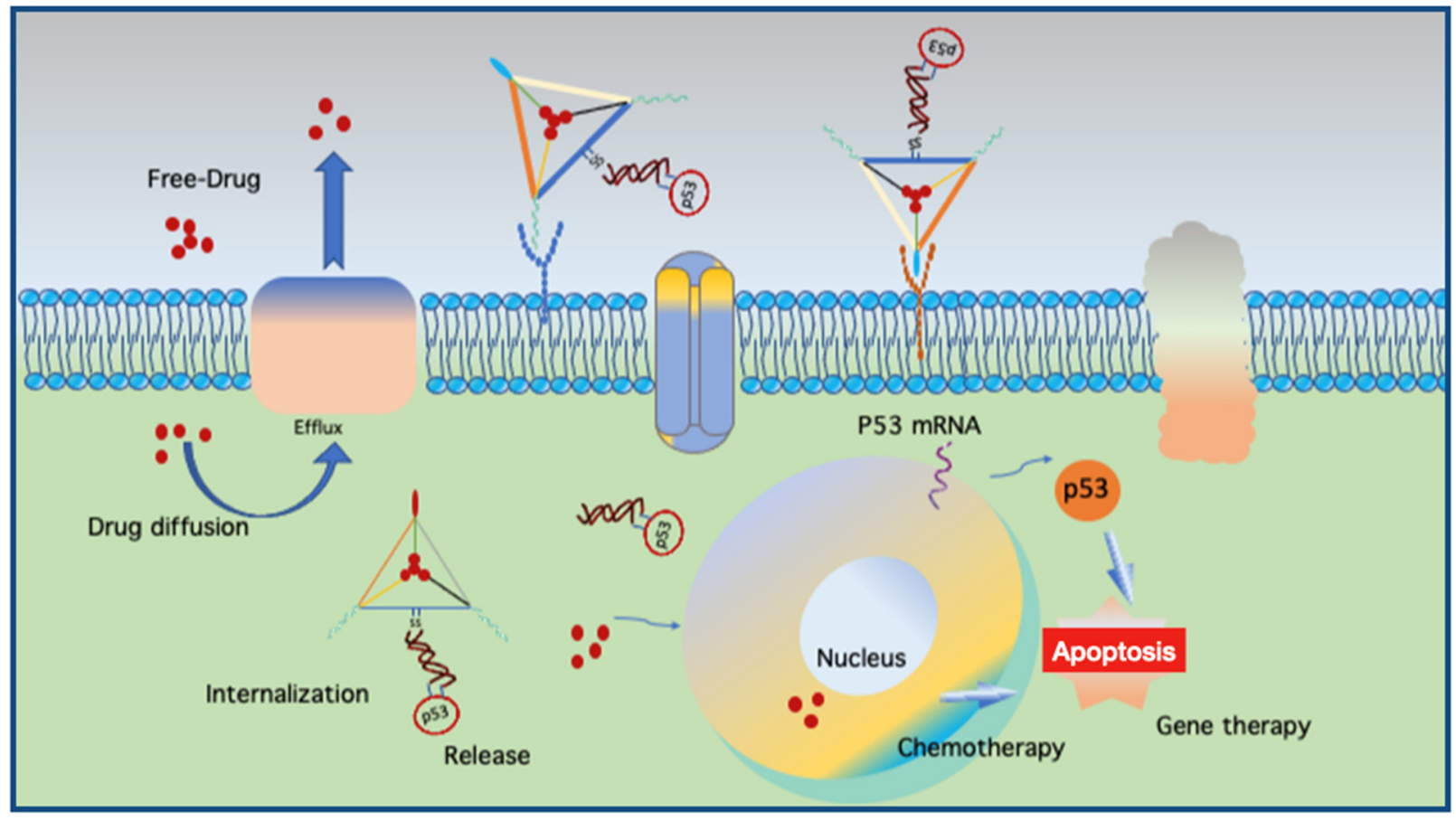

Figure 4. The molecular mechanism involved in circumventing multiple-drug resistant (MDR) cells and the dual therapy of cancer cells. MDR cells excrete drugs via an efflux pump and the DNA nanostructure can deliver the drug into the cell via cellular uptake through endocytosis. The drug is released through $\mathrm{pH}$-dependent conditions and subsequently delivered to the nucleus to induce apoptosis. DNA nanostructures equipped with both drugs and tumor therapeutic genes can codeliver dual chemotherapeutic and gene therapeutic effects to MDR cancer cells. Illustration inspired from [50].

\subsection{Therapeutic Nucleic Acid Delivery}

In addition to drug delivery, DNSs have also been employed to deliver functional therapeutic nucleic acids such as aptamers, antisense RNAs, small interfering RNAs (siRNAs), microRNAs, and antisense oligonucleotides.

Cytosine-phosphorothioate-guanine oligodeoxynucleotides (ODNs), which contain phosphodiester links between $C$ and $G$ nucleotides, are potent activators of innate and acquired immune responses. $\mathrm{CpG}$ sequences that are more abundant in bacterial genomes than in mammalian genomes [88] are considered pathogenic signals by the immune system and can stimulate Toll-like receptor 9 (TLR 9), resulting in the secretion of inflammatory cytokines [89], leading to immunotherapeutic properties. Due to their susceptibility to nucleases, $\mathrm{CpG}$ sequences alone cannot reach the desired target sites. Therefore, modifications have been designed to achieve stability, such as phosphorothioate (PS) backbones, high-order tertiary structures via the formation of poly $(\mathrm{G})$ motifs, and PS backbones in dumbbell-like structures [90]. Nishikawa et al. prepared Y-shaped oligodeoxynucleotides (Y-ODNs) using three ODNs with half of each ODN partially complementary to half of the other two ODNs [91]. Y-ODNs induced a higher level of tumor necrosis factor- $\alpha$ and interleukin-6 from RAW264.7 macrophage-like cells and higher cytokine levels than dsODNs containing identical sequences. This Y-shaped DNA was further developed into a larger dendrimer-like structure (DL-DNA) $[92,93]$. DNA immunonanoflowers (NFs) as multivalent $\mathrm{CpG}$ nanoagents were developed from long DNA molecules integrated with tandem CpG sequences through rolling circle replication [94] for efficient CpG delivery and protection from nuclease degradation [95]. Zhu et al. also integrated NFs with aptamers, bioimaging agents, and drug-loading sites as proof-of-principle demonstrations [53]. Mohri et al. assembled multiple CpG sites to form a multi-branch Y-X or dendrimer-like 
polypod structure [96]. An increasing number of pods (from three to eight pods) is directly linked to better stability, efficient cellular uptake, and increased cytokine production.

In addition to integrating CpG sequences into a larger DNA sequence, Li et al. employed functional 3D DNA tetrahedra with CpG appendices at each corner to achieve the non-toxic and stable delivery of CpG to RAW264.7 cells [97]. Such a structure can protect $\mathrm{CpG}$ sequences from nuclease degradation and remain intact for at least seven hours. After cellular uptake, $\mathrm{CpG}$ motifs activate downstream pathways to induce immune responses. Interestingly, Liu et al. applied DNS along with antigen and CpG adjuvants to develop a synthetic vaccine [49]. As in a previous study, CpG sequences were conjugated to the corners of a DNA tetrahedron, and a model antigen (streptavidin) was embedded inside the DNA tetrahedron. From their results, the antigen-CpG-DNS complexes induced longlasting and robust antibody responses against the antigen without stimulating a reaction to the DNS itself, indicating the potential application of DNSs in developing more effective vaccines. Schuller et al. applied another form of DNS with CpG to investigate the potential of DNA origami constructs as programmable and noncytotoxic immunostimulants [98]. In this study, a hollow 30-helix DNA origami tube $(80 \mathrm{~nm} \times 20 \mathrm{~nm})$ was covered with up to $62 \mathrm{CpG}$ sequences and tested for immune responses in freshly isolated spleen cells. Such decorated origami tubes triggered higher immunostimulation than an equal amount of CpG using Lipofectamine, a common transfection agent. They also found a lack of immune response to nanotubes without CpGs and showed no detectable toxicity compared to Lipofectamine. These findings indicate that DNS is a suitable candidate for transporting CpGs into target cells, providing safe and enhanced cellular uptake with less toxicity, thus serving as a better alternative to commonly used transfection agents. DNA can be used to deliver CpG ODNs for immunization purposes with or without antigens (Figure 5).

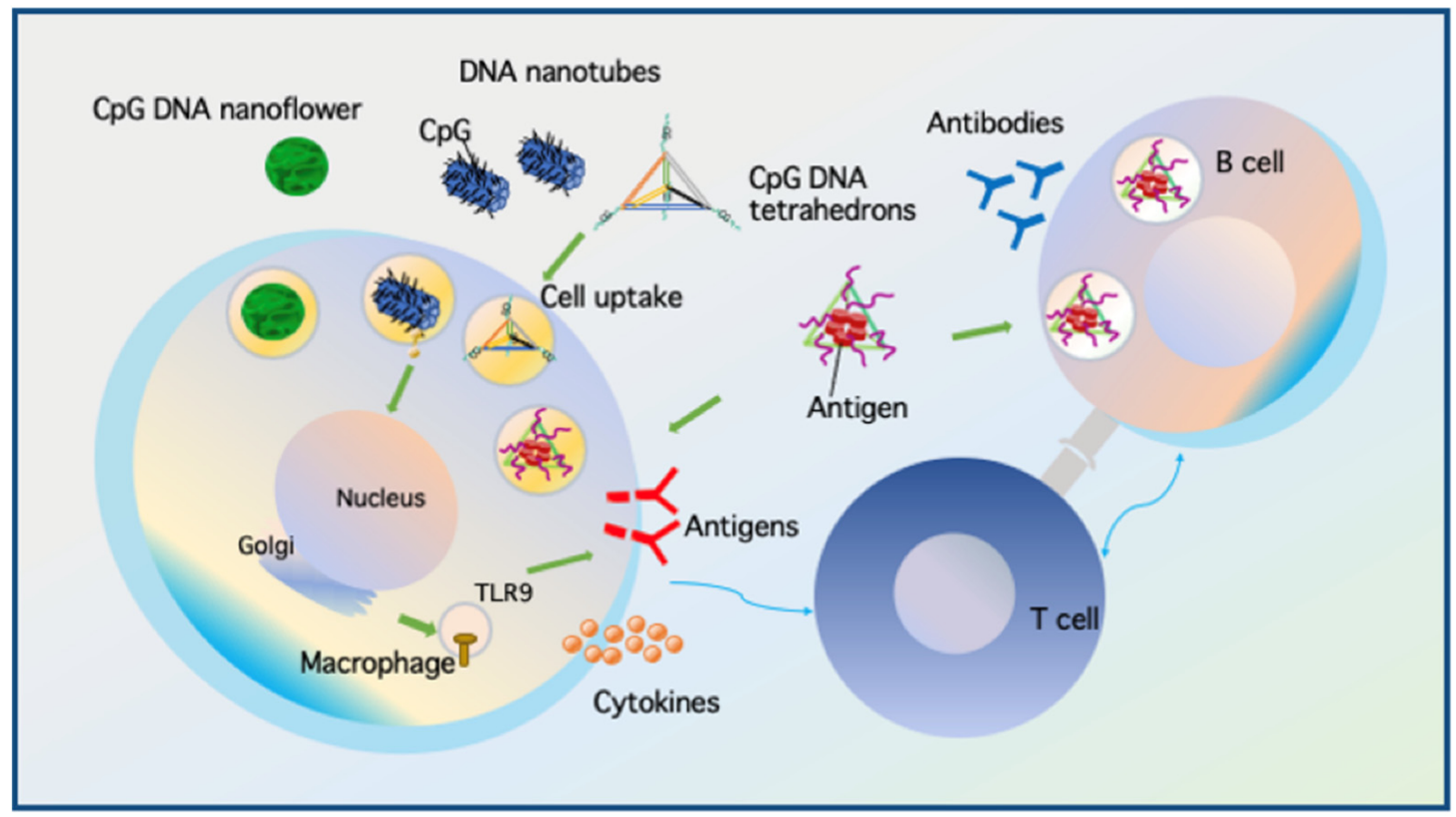

Figure 5. DNA nanostructures act as a synthetic vaccine by carrying CpG ODN with or without antigens to activate immune cells. DNS without antigens enter macrophages and deliver CpG ODN recognized by Toll-like receptor (TLR)- 9 that can stimulate the cell to produce antigens and cytokines. DNS with antigens specifically enters B cells and non-specifically to macrophages. $T$ cells then activate the B cell response leading to antibody production. Illustration inspired from [49].

The AS1411 aptamer, a potential cancer therapeutic agent by itself or in combination with other drugs, was incorporated into DNA pyramids to achieve enhanced cellular uptake 
and selectivity [99]. DNA pyramids also protected single-stranded aptamers from nucleases while inhibiting HeLa cell growth within $24 \mathrm{~h}$. In cancerous cells, the aptamer alone could enter through the micropinocytosis pathway and escape endolysosomal degradation. In contrast, in non-cancerous cells, AS1411 can end up in the lysosomes. AS1411-pyramids behave similarly to the aptamer alone cellular uptake mechanism of ending up in the lysosomes of normal cells, thereby preventing adverse effects on normal cells.

Lee et al. used TDNs to deliver siRNAs into tumor cells and silence target genes in tumors [100]. By applying folic acid as ligands, they observed that at least three folate molecules per nanocarrier were required for the optimal delivery of siRNAs into cells. Moreover, gene silencing only occurs when the ligands are in an appropriate spatial orientation. Kim et al. applied wireframe TDN with a 20-mer duplex on each side to deliver siRNA into the liver targeting ApoB1 mRNA which is overexpressed in hypercholesterolemia [101]. In vivo and ex vivo images of BALB/c mice showed that duplex siRNA (siApoB1) was able to reach the liver with lower accumulation level than that of Td-siApoB1. Accumulation of Td-siApoB1 in the liver can result in the downregulation of ApoB1 protein leading to the decreased blood cholesterol level. Xue et al. also employed TDNs as building blocks to construct a DNA-based nanogel in which siRNAs and DNA tetrahedra are crosslinked by a specific sticky end to deliver siRNA [102]. A framework DNA tetrahedron with a tail and a single-stranded DNA molecule complementary to each end of the siRNA linkers acts as a building block to mix with siRNA linkers at an optimized ratio of 1:1.8 to assemble into a crosslinked nanosized hydrogel. They stated that the nanosized 3D nanogel prevents the nuclease digestion of the loaded siRNA; however, at the same time, RNase H-mediated cleavage can release the siRNA inside the cell. Similarly, Fu et al. developed a smart pH-responsive DNA nanohydrogel system as a carrier for the delivery of mRNA into HeLa cells [103]. They designed X-shaped DNA scaffolds and DNA linkers with i-motif sequences to crosslink the target mRNA to form the nanohydrogel with a compact spherical shape. The dehybridization with the scaffolds occur at an acidic $\mathrm{pH}(\mathrm{pH} 4.5-5.0)$ releasing the mRNA. They claimed that the nanohydrogel system showed better biocompatibility and comparable mRNA expression efficiency relative to the commercial liposome. Such a system can become an alternative to the liposome for delivering small RNA molecules.

RNA interference (RNAi) is a therapeutic strategy that induces gene silencing by targeting disease-causing mRNAs removed through degradation pathways. Fakhoury et al. applied 3D DNA cages in the shape of a triangular prism (TP) integrated with nucleic acid therapeutics, an antisense oligonucleotide for firefly luciferase, at one, two, four, or six sites for transfection into HeLa-Firefly Luciferase cells [104]. The outcome was superior to that of single-stranded and double-stranded controls, with a slight premature dissociation of the antisense oligonucleotides from the DNA scaffold. TPs with four and six antisense strand positions maintained gene silencing up to $72 \mathrm{~h}$ and were more robust at gene knockdown after removal. For the encapsulation and conditional release of siRNA, Bujold et al. designed DNA nanosuitcases that can enclose a siRNA construct and release it upon recognizing mRNA or microRNA (miRNA) oligonucleotide RNA [105]. Upon recognizing the marker, the two gating strands were unwound via strand displacement, releasing the siRNA [106]. The design can be modified for dual therapy purposes, with the gating strands as antisense strands performing gate opening and gene silencing. Such a design was reported to be effective in increasing half-life, protecting siRNA, controlling release, and having the potential for diverse applications with logic gates that can be tailored to the biological system of interest.

\subsection{Delivery of Gene Editing Tools}

The RNA-guided Cas9 nuclease from the microbial clustered regularly interspaced short palindromic repeat (CRISPR) immune system can facilitate gene editing and genome engineering in eukaryotic cells by simply specifying a 20-nucleotide targeting sequence within its guide RNA [107]. The CRISPR/Cas genome editing system can be engineered to target almost any gene of interest with precise and efficient gene editing in various cells. 
The major obstacle in its application is the delivery of the system to target cells. Currently, viral vectors are the most used vehicles for cell delivery, but they can also contribute to the adverse effects of genetic diseases and off-target side effects. Sun et al. synthesized DNA nanocarriers via rolling circle amplification to transport a Cas9/sgRNA complex into the cell nucleus [52]. Yarn-like nanocarriers were loaded with Cas9/sgRNA complexes through Watson-Crick base pairing. This, in turn, was encapsulated in a coating of the cationic polymer polyethyleneimine to help induce endosomal escape. Nuclear transportation was achieved via nuclear-localization-signal peptides fused to Cas9. According to the flow cytometry results, the mutation frequency in cells treated with DNA nanocarriers was 18-fold higher than that in cells without DNA nanocarriers. They reported that the partial complementarity between DNA nanoclews and sgRNA guide sequences promoted the extent of gene editing probability by balancing the binding and release of the Cas9/sgRNA complex. Liu et al. employed a branched DNA nanoplatform via covalent crosslinking to deliver the sgRNA/Cas9/antisense complex for synergistic gene silencing and tumor therapy in vitro and in vivo [108]. They also incorporated aptamers for cell targeting and a peptide for endosomal escape, attempting to achieve the anti-tumor effects of gene editing (DNA in the nucleus) and gene silencing (mRNA in the cytoplasm) in vivo (Figure 6). These findings indicate the potential of DNA nanotechnology in genome editing in the future, and similar purposes of CRISPR/Cas9 delivery can be achieved using virus-like designs of DNA nanocarriers.

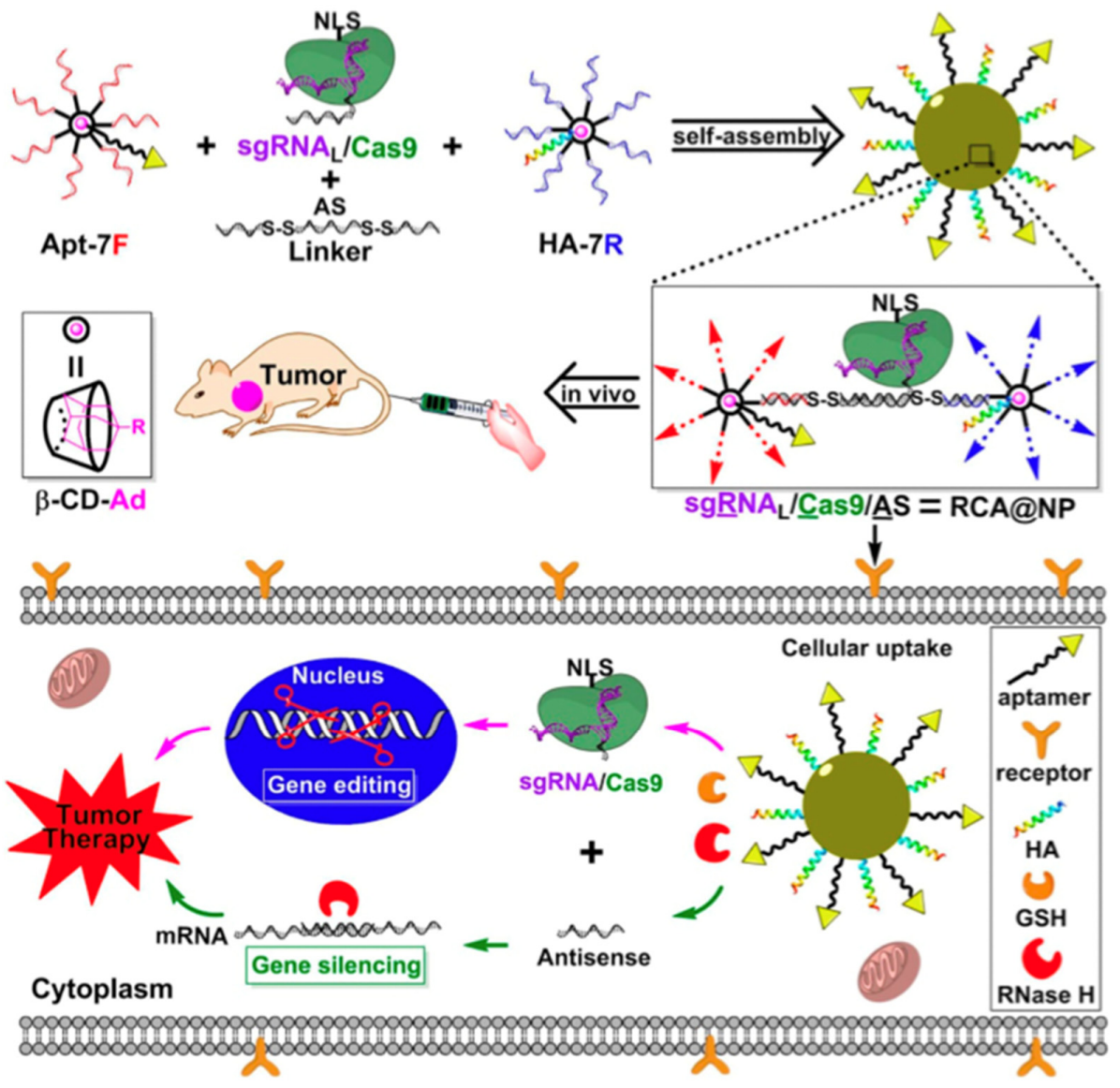

Figure 6. Model of DNA nanostructure that co-deliver gene editing and gene silencing to the cell. DNA nanostructures base-paired with the sgRNA/Cas9 and covalently crosslinked with antisense strands enter the cell via endocytosis. Antisense strands are released by RNase $\mathrm{H}$ and bind to messenger RNA for gene silencing. The CRISPR complex enters the nucleus to perform gene editing while the multifunctional nanocarrier provides synergistic tumor therapy. 7F or 7R: DNA oligonucleotides covalently crosslinked by beta-CD. Reproduced with permission from [108] Copyright (C) 2022 American Chemical Society. 


\section{DNA Nanorobots That Deliver Molecular Payloads}

The controlled release of drugs has been achieved with diverse nanomaterials that can react to environmental stimuli such as variations in $\mathrm{pH}$, temperature, and magnetic field strengths. Using several approaches, such materials can not only respond to biochemical or physical stimuli but can also be programmed to use logic gates for analysis. In biocomputing based on the interactions of biomolecules, different approaches can be applied to create logic gates, identify general algorithms, and obtain output signals from the inputs. The implementation of logic-gated systems in DNS was pioneered a decade ago by Douglas et al. who designed a prototype of DNA origami-based nanorobots for the smart delivery of molecular payloads [109]. They adapted a DNA box with a controllable lid from a previous report [110] to use as a 3D DNA box in the form of a hexagonal barrel with dimensions of $45 \times 35 \times 35 \mathrm{~nm}^{3}$. The barrel consists of two domains, in the form of an empty box and a lid, where single-stranded scaffold hinges are located at the back and staples modified with DNA aptamer-based locks are located at the front. In this case, (Figure 7a), the aptamer is a lock that can be opened by binding to the antigen keys, which are designed to operate in response to proteins, based on [111].

Structure-switching aptamers undergo target-induced switching between an aptamercomplement duplex and aptamer-target complex. When aptamers recognize their targets, the lock duplexes dissociate and the nanorobot undergoes a drastic reconfiguration. Molecular payloads can be loaded through a short ssDNA oligonucleotide linker inside the nanorobot. They are intended to load at least two molecules per robot for multivalent interactions with the surface receptors [112]. Dogulas et al. applied gold nanoparticles and Fab antibody fragments that can attach to a protein marker on the surface of the cell of interest so they can consequently interact. These agents were programmed to be activated in response to a single input using the same aptamer sequence on the right and left sides. If different aptamers are used, the nanorobot can only be opened in the presence of two inputs; in other words, two different keys are required to open the two locks. These logic gates of inputs of binding or non-binding ( 0 or 1 ) that lead to outputs of closed or open states ( 0 or 1$)$ in nanorobots are equivalent to a logical AND gate. Amir et al. designed a system with various logic gates, such as AND, OR, and XOR, with DNA origami robots in living cockroaches to control molecules that target their cells [113]. Hypothetically, their system serves as a processor that can deliver a therapeutic response to a different disease state based on a selection of three drugs. The system consists of eight robot types: three effector robots, each carrying a different drug, four positive regulators and a negative regulator. They altogether set up two first-layer gates, AND and OR, each controlling its own drug relaying its output state to a second-layer XOR gate which controls a third drug (Figure 7c). Four drug combination outputs could be generated by using such a model system. Yang et al. performed a set of logic gates (OR, YES, and AND) in response to the stimuli of adenosine triphosphate (ATP) and cocaine with an aptamer-binding DNA origami pattern [114]. Small DNA tiles were controlled to fill the predesigned DNA origami frame by combining DNA aptamer-substrate binding and DNAzyme-cutting (Figure $7 \mathrm{~b}$ ).

One of the most promising applications of DNA nanorobots was reported by Li et al., who applied nanoscale DNA robots as intelligent drug delivery systems that respond to molecular triggers in vivo for cancer therapy. They used a DNA nanorobot that delivered thrombin, a coagulation factor, and a serine protease specifically in tumors [76]. In their DNA nanorobot design, a rectangular origami sheet was prepared from M13mp18 single-stranded DNA with predesigned staple strands. Thrombin was loaded onto the surface of the DNA sheet structure via poly-T and poly-A oligonucleotide hybridization (Figure 8a). When fasteners and aptamers are added, the sheet forms tubular DNA nanorobots that carry thrombin that can target aptamers at both ends. The nanocarrier tube opens when nucleolin, a protein highly expressed in the tumor, is present. In the open state, encapsulated thrombin induced localized thromboses, tumor infarction, and cell necrosis (Figure $8 b$ ). They demonstrated that nanorobots not only affected the primary tumor, but also prevented metastasis in a melanoma mouse model. They reported the safety and 
inert immunological activity of nanorobots in mice and Bama miniature pigs. They also intended to further develop the current strategy as a drug delivery method for treating other diseases by modifying the geometry of the nanostructures, targeting groups, and loaded cargo. Similar to a previous study [76], Liu et al. [115] recently designed a tetrahedral DNA nanorobot that responds to molecular triggers to perform a conformational change when targeting tumor cells. A 2D DNA origami sheet (DOS) was folded into a 3D tetrahedral DNS using multiple parallel-folding elements. The folding of the DOS was aided by five pairs of DNA molecules containing SYL3C aptamer sequences that target epithelial cell adhesion molecule (EpCAM), a molecule specifically expressed on circulating tumor cells. When the aptamers bind to EpCAM, the TDN is triggered by EpCAM to unfold into a DOS to expose the molecules or drugs inside; in this case, a fluorescent dye was used for visualization (Figure 8c).

(a)

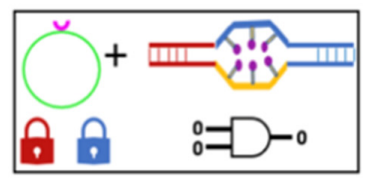

(b) (i)

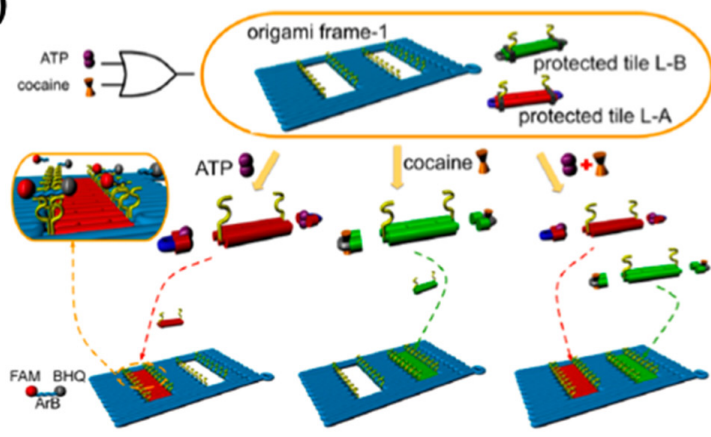

(c)

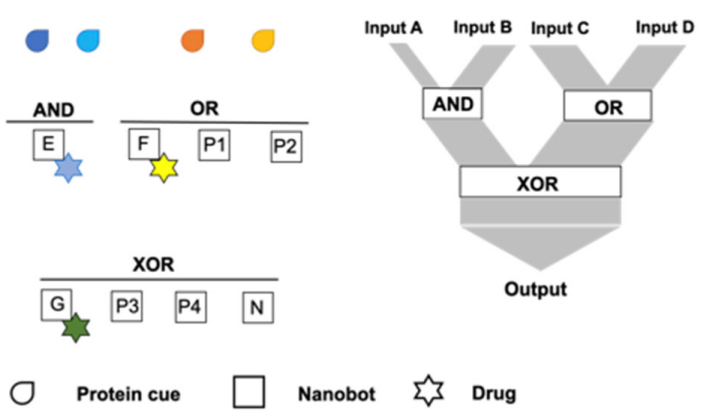

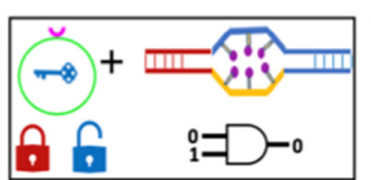

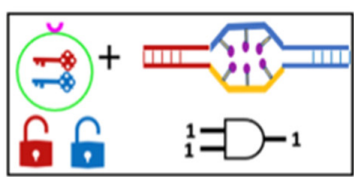

(ii)
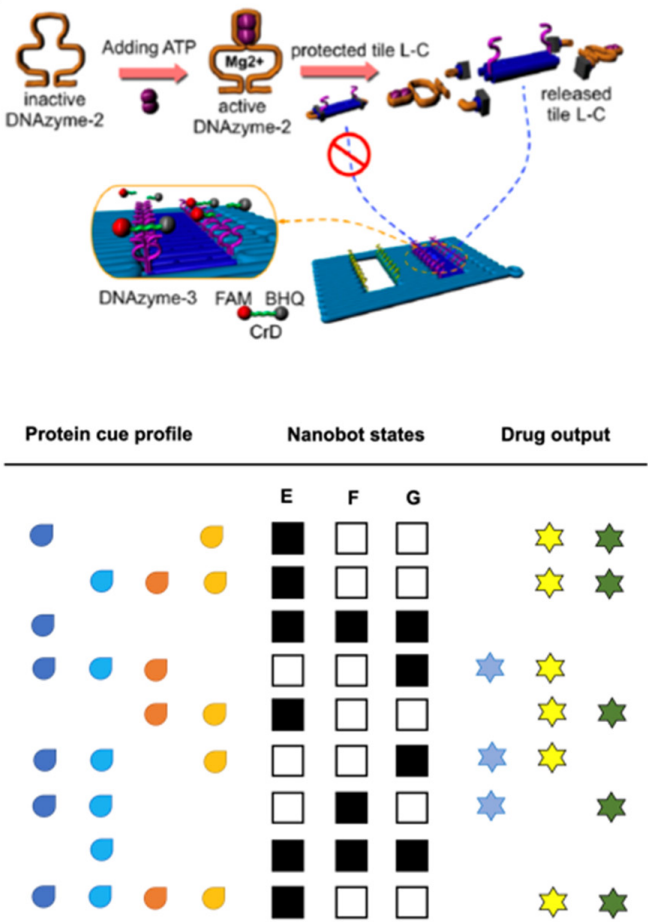

Figure 7. Logic-gated nanorobots; inputs (A, B), outputs (1,2). (a) Nanorobot activation via an AND logic gate. The aptamer-encoded locks respond to molecular input (key)-expressing cells leading to the conformational change of the nanorobot as an output. Redrawn from [109]. (b) Aptamerbinding directed DNA origami pattern for logic gates: (i) operation of an OR logic gate through a DNA origami using ATP and cocaine as two independent inputs to trigger the filling patterns, and (ii) operation of a two-layer YES gate where an active DNAzyme is designed to leave the protected tile to prevent direct filling into the origami. Adapted with permission from [114]. Copyright (C) 2022, American Chemical Society. (c) A hypothetical system consisting of eight robot types capable of simultaneously controlling three therapeutic molecules: three effector robots $\mathrm{E}, \mathrm{F}$, and $\mathrm{G}$, each carrying a different drug; four positive regulators, P1 and P2 keying F, and P3 and P4 keying G; and a negative regulator $\mathrm{N}$ inactivating $\mathrm{G}$ forming two first-layer gates, $\mathrm{AND}$ and $\mathrm{OR}$, each controlling a respective drug while relaying its outputs to a second-layer XOR gate that controls the third drug. Redrawn from [113]. 

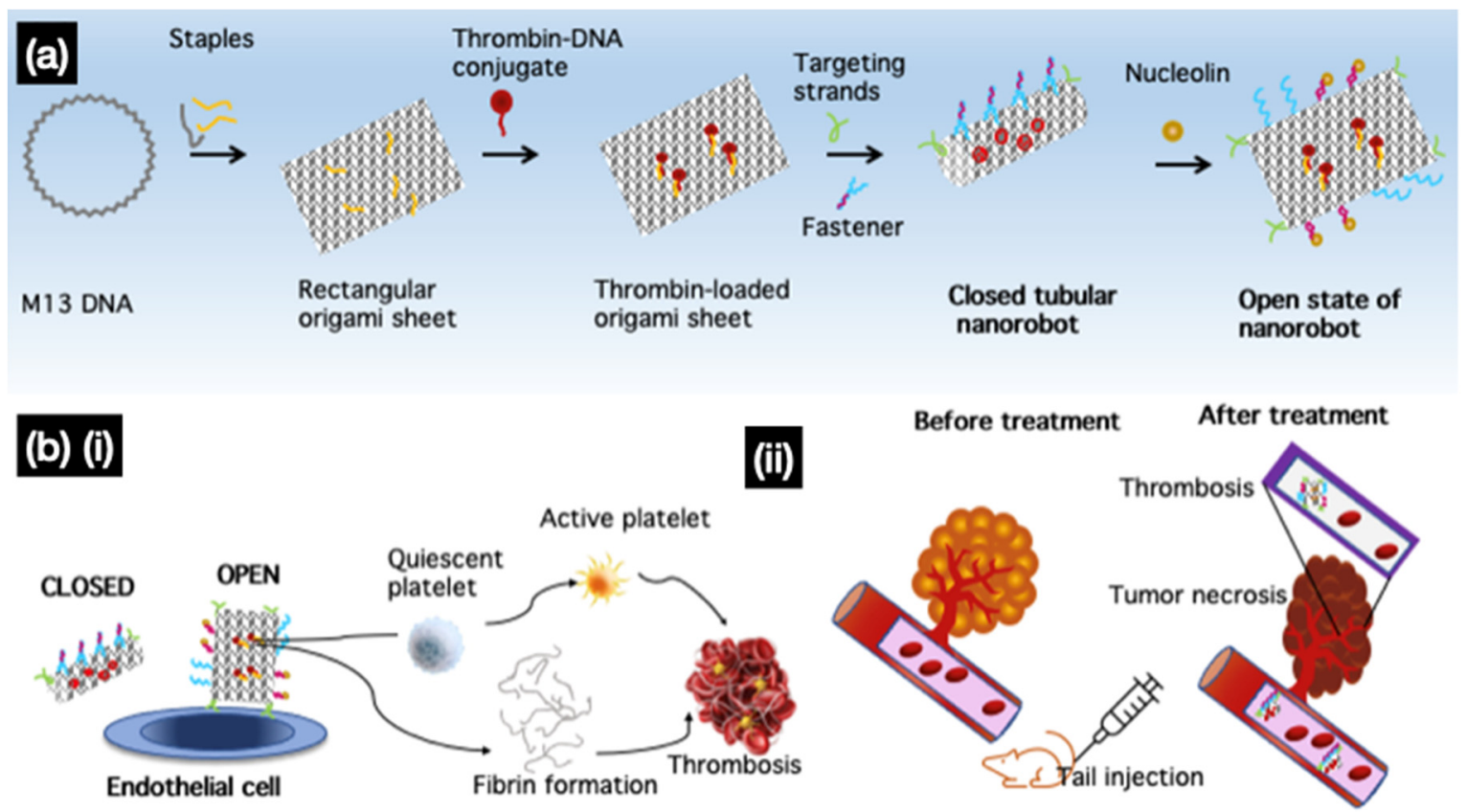

(c)

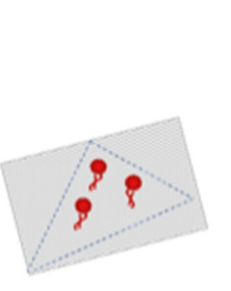

DNA origami sheet with payload

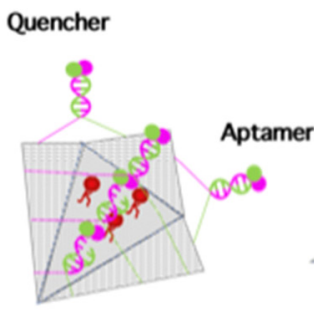

Three folds in sync

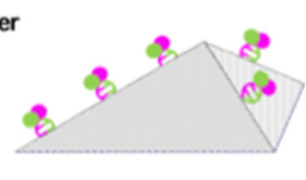

Tetrahedral DNA nanorobot (High stability)

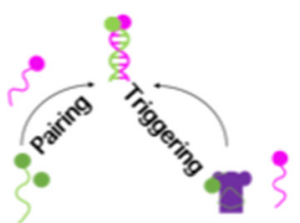

Locking/unlocking mechanism

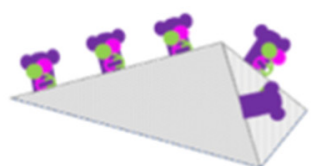

Conformational change of TDN triggered by molecular marker

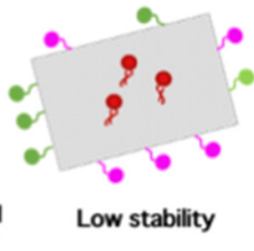

Figure 8. Application of DNA nanorobots for targeted therapy. (a) Construction of a nanorobot-Th through DNA origami. The closed tubular nanorobot opens upon sensing nucleolin to open the DNA origami sheet. (b) (i) The mechanism of action of nanorobot-Th in plasma in the presence of vascular endothelial cells. (ii) The therapeutic mechanism of nanorobot-Th within tumor vessels. DNA nanorobot-Th administered to tumor xenografted mice via tail vein injection binds to the vascular endothelium by recognizing nucleolin and opens to expose its thrombin cargo which induces localized thromboses, tumor infarction, and cell necrosis. Redrawn from [76]. (c) Dynamic DNA nanostructures that respond to external stimuli can perform a conformational change; a DNA rectangular sheet that can fold synchronously into a tetrahedral DNA nanorobot driven by five aptamer duplexes. Through a locking and unlocking mechanism, in response to epithelial cell adhesion molecule (EpCAM), a TDN undergoes a conformational change back to the DNA origami sheet that exposes its payload (a red fluorescence dye in this case). Redrawn from [115].

\section{Tetrahedral Framework Nucleic Acids as Therapeutic Agents}

Recently, tetrahedral framework nucleic acids (tFNA) have been widely used as therapeutic targets for neurological disorders. For example, Li et al. employed aptamerconjugated framework nucleic acids to repair cerebral ischemia-reperfusion injury (IRI) in an animal model [116]. Oxidative stress and excessive inflammation are the main causes of IRI and can lead to neuronal damage and disability. Complement component 5a (C5a) exacerbates stress and immune responses. By applying a framework nucleic acid 
(FNA) conjugated with anti-C5a aptamers, which can selectively reduce C5a-mediated neurotoxicity, the group performed an intrathecal injection in mice to reduce oxidative stress. The structure of the framework is equivalent to two pyramids (tetrahedra) stacked on top of each other, with protruding aptamers. They hypothesized that C5a-FNA could function to scavenge free radicals and block C5a-mediated neurotoxicity to inhibit cerebral IRI and found that such conjugates functioned as antioxidants at the cellular level to protect primary neurons from oxidative stress. This study indicated the potential of DNS in neural therapy for several purposes, with suitable modifications for the designated diseases to be cured.

Another example of the application of DNSs in neural science was performed very recently by Zhou et al. in glioma cells using a DNA tetrahedron as a surviving siRNA carrier to combat brain tumors [117]. Another group also constructed a tetrahedral DNS-loaded surviving interfering RNA (As-TDN-R) to selectively identify tumor cells overexpressing nucleolin, which is highly expressed in various tumors and can promote tumor progression [118]. Nucleolin also acts as a ligand for the aptamer AS1411 and supports its cellular entry [119]. Owing to the potential of nucleolin as a glioma marker, since there is a differential expression of nucleolin between glioma cells and normal cells, the AS1411-attached nanostructures showed differences in intercellular uptake, although its exact mechanism remains unclear. The structure equipped with aptamers for cell targeting increased siRNA delivery and efficiently induced apoptosis in glioma cells, which were activated by inhibiting survivin expression. Shi et al. performed similar aptamer-modified tFNA for targeted glioma therapy [120]. They employed tFNA to deliver two aptamers, GMT8 and Gint4.T, and an anti-tumor drug, paclitaxel, into U87MG and bEnd.3 cells without the aid of transfection agents. The linkage of tFNA with aptamers alone and aptamers with the drug showed anti-glioma efficacy. In addition to neurological disorders, Xie and colleagues tested TDNs loaded with paclitaxel to treat drug-resistant lung cancer, where paclitaxel solutions of different concentrations were incubated with TDNs at room temperature for $24 \mathrm{~h}$ to recover the drug-loaded white precipitate after centrifugation [121].

Furthermore, tFNAs have been reported to be neuroprotective [122], antioxidant [123], and anti-inflammatory agents [124]. Chen et al. applied tFNA without the conjugation of therapeutic agents or functional agents to target Alzheimer's disease [125]. While the therapeutic properties of tFNA are not yet fully understood, they reported the inhibition of apoptosis and reduction in amyloid beta proteins in the brain, in addition to the ability to partially pass the blood-brain barrier. They proposed that the function of tFNA in Alzheimer's disease models involves inhibiting the mitochondria-dependent apoptotic pathway. First, tFNA reduces the level of reactive oxygen species (ROS), thereby reducing the activation of caspases, inhibiting the apoptosis-related signaling pathway, and finally inhibiting apoptosis. Similarly, to explore potential alternative therapies for multiple sclerosis, Yang et al. characterized the effects of tFNA on remyelination [126]. They reported that these nucleic acids could accelerate remyelination and enrich myelinated axons by restoring the expression of myelin-related proteins. Inhibiting apoptosis, in addition to inhibiting the abnormal activation and proliferation of microglia and astrocytes, relieves inflammatory reactions in vivo. Such outcomes were proposed to be obtained via tFNAs upregulating the phosphorylation of the PI3K-AKT-mTOR signaling pathway.

The role of this pathway was also reported by Yao et al. who employed tFNAs to facilitate the restoration of facial nerves [124]. They reported that tFNAs can regulate the neurorestorative pathway in activating a series of cell behaviors related to injured nerve restorations, along with enhanced expression of axon and myelin marker proteins, histological recovery, and muscle movement in vitro and in vivo. Li et al. explored the effect of tFNA on the wound healing using corneal epithelial wound as an example [127]. They reported the enhanced proliferation of human corneal epithelial cells upon exposure to tFNAs in vitro. In vivo experiment with animal model of corneal alkali burns through clinical evaluations and histological analyses showed the improved corneal transparency and re-epithelialization of wounds. The application of DNSs as therapeutics is not limited 
to tFNAs, other DONs were also shown to apply as such application. Jiang et al. applied radiolabeled DONs with three different shapes, rectangular, triangular, and tubular, as therapeutic agents to treat acute kidney injury (AKI) [128] which frequently requires kidney transplantation. When applied to murine models of induced AKI, DNA origami scavenges ROS, alleviates oxidative stress, protects the kidney, and alleviates AKI. Among the biodistribution patterns of the three different DNA origami, all three performed better than short ssDNA, M13 ssDNA, and partially folded DNA origami. Rectangular DNA origami showed renoprotective properties with efficacy similar to a clinically used drug. A similar approach in the therapy of acute kidney injury was recently adapted by Chen et al. where they applied rectangular DONs (rDONs) by upgrading as a nanodevice with antiC5a aptamers (aC5a) to block the C5a-mediated inflammation [129]. aC5a-rDONs allowed for the local protection from oxidative stress by scavenging ROS in stage I and suppress the inflammatory responses by blocking $\mathrm{C} 5 \mathrm{a}$ in stage II in a renal ischemia-reperfusion (I/R model).

Similar to the application of other DNSs to deliver the small RNA molecules into the cells, the potential application of tFNA has been extended to apply to deliver microRNA (miR). Recently, Li et al. applied tFNA to deliver miR-2861 (model miR) to target the expression of histone deacetylase 5 (HDAC5) in bone marrow mesenchymal stem cells [130]. To achieve the successful separation of the miRs from tFNA after the cell entry, they connected a sticky-end tFNA and miR-2861 via an RNaseH-responsive sequence. They fabricated this bioswitchable delivery system with (i) the protection of miRs in the form of doublestranded RNA, (ii) the transport of miRs with tFNA cell-entrance ability, (iii) RNaseH attribute to unload the miRs to avoid the involvement of tFNA in subsequent biochemical reactions, and (iv) the thermodynamic stability of the $5^{\prime}$ end of the guide strand enables the formation of the RISC. The images of hematoxylin and eosin (H\&E) staining showed that the regenerated bone tissue in the stFNA-miR group had filled the entire bone defect area while other groups exhibited some non-osteogenic areas. Masson's trichrome staining showed that the stFNA-miR group exhibited a significantly higher collagen fiber content than the control and other groups after one and two weeks. Another group, Qin et al. developed microRNA-155-equipped tFNAs (T-155) and determined the effects on choroidal neovascularization (CNV) [131]. They targeted macrophages instead of targeting vascular endothelial growth factor. They reported that T-155 can enter the cell and bind to the target gene to reduce its expression while improving the pathology of CNV by polarizing macrophages to M1 type.

Interestingly, Zhang et al. employed tFNA to deliver antisense oligonucleotides (ASOs) against multiple targets in bacterial cells to inhibit biofilm formation [132]. Extracellular polysaccharides (EPS) and bacteria can cause biofilms to become adherent, toxic, resistant to antibiotics, and ultimately difficult to remove. They selected Streptococcus mutans (S. mutans) biofilm that is related to the onset of various oral disease targeting $g t f B C D, g b p B$, and fif genes. They demonstrated that ASOs-tFNAs could penetrate the cell wall of $S$. mutans, targeting multiple genes in the early stages of biofilm formation and improving the inhibitory action using confocal and scanning electron microscope. The biofilms treated with $750 \mathrm{nM}$ ASOs-tFNAs showed a significant reduction in EPS with more porous and spongier structure in comparison with tFNAs and ASOs alone treatments. Another application of tFNA was demonstrated to deliver antimicrobial peptides (AMPs) by Liu et al. [133]. They combined tFNA with an AMP, GL13K, and investigated the effects of resultant complexes against Escherichia coli (E. coli) that is sensitive to GL13K and Porphyromonas gingivalis (P. gingivalis) that can degrade GL13K. While AMP-tFNA increased the effects against $E$. coli, the tFNA protected the peptides against $P$. gingivalis serving as a suitable delivery vehicle for AMPs targeting a broad range of diseases. These findings highlighted the versatility of tFNA in combating several defects and diseases. Examples of some of the publications that applied tFNAs alone or with modifications for therapeutic purposes are listed in Table 3. For an in-depth report on the design, fabrication, and applications of 
tFNA-based multifunctional complexes in drug delivery and biomedical treatment, we direct the readers to the intensive work reported by Zhang et al. [134].

Table 3. Tetrahedral framework nucleic acids applied as therapeutic agents in neural diseases.

\begin{tabular}{|c|c|c|c|}
\hline tFNA Design & Targeted Disease & Results & Ref. \\
\hline tFNA with aptamer conjugation & Cerebral ischemia-reperfusion & Alleviate oxidative stress & [116] \\
\hline tFNA-aptamer to deliver siRNA & Glioma cells & Apoptosis & [117] \\
\hline tFNA & Alzheimer's disease & Apoptosis & [135] \\
\hline tFNA with aptamer and paclitaxel nanoconjugates & Glioblastoma & Apoptosis & [120] \\
\hline tFNA loaded with Temozolomide & Glioblastoma & Apoptosis, Autophagy & [70] \\
\hline tFNA & Parkison's disease & Apoptosis, differentiation & [135] \\
\hline tFNA & Alzheimer's disease & Apoptosis & [136] \\
\hline tFNA & Retinal ischemia-reperfusion & Apoptosis & [137] \\
\hline tFNA & Spinal cord injury & Apoptosis & [138] \\
\hline tFNA loaded with SiCCR2 & Intracranial hemorrhage & Anti-inflammation & [139] \\
\hline tFNA & Facial nerve injury & Proliferation, differentiation & [124] \\
\hline tFNA with microRNA-22-3p & Glaucoma & Apoptosis, proliferation & [140] \\
\hline tFNA with Vitamin B12 & Parkinson's disease & $\begin{array}{l}\text { Autophagy, proliferation, } \\
\text { differentiation }\end{array}$ & [141] \\
\hline
\end{tabular}

\section{DNA Nanostructures Interacting with the Cell Membrane}

In addition to drug delivery into cells, DNSs have been tested to interact with lipid membranes for synthetic biological purposes, such as cell signaling pathways, cell-cell adhesion, and synthetic DNA nanopores in artificial cell systems. It has long been known that cationic lipids can be used to transfect DNA into hard-to-transfect cell types [142] and to deliver siRNA into cells [143-146] while negatively charged lipids can repel DNA. The affinity between DNA and negatively charged lipids can be enhanced with positively charged divalent cations $\left(\mathrm{Mg}^{2+}, \mathrm{Ca}^{2+}\right)$ and reduced with monovalent ones $\left(\mathrm{Na}^{+}, \mathrm{K}^{+}\right)$. While the mechanism is not fully understood, this effect can probably result because divalent cations bridge from the phosphate backbone of DNA to the negatively charged pole of lipid heads. On the other hand, monovalent cations can reduce this affinity with the lack of bridging and the presence of competitive binding. Different lipid states, such as liquid-disordered (Ld) and solid-ordered (So) states, may also influence how DNA origami behaves on the lipid membrane. A demonstration of the lipid phase-dependent behavior of DNA origami structures was achieved using giant unilamellar vesicles (GUVs) and supported lipid bilayers, suggesting that 2D lattices from cross-shaped DNA origami were formed in the Ld phase while DNA origami aggregated in the So phase [147]. In nature, hydrophilic DNA does not interact with or cannot be inserted into the hydrophobic lipid bilayer. Hydrophobic anchor molecules, such as cholesterol, porphyrin, or polypropylene oxide, are required to strengthen the association between DNA structures and lipid membranes.

Cholesterol is the most commonly used membrane anchor because it can easily be attached to DNA at the $5^{\prime}$ or $3^{\prime}$ end during DNA synthesis through a triethyleneglycol spacer. Most DNA nanopores (Table 4) employ various amounts of cholesterol anchors for membrane channels. Burns et al. applied a different approach from cholesterol with porphyrin-based hydrophobic tags to achieve the anchoring of the negatively charge DNA nanopore into the lipid bilayer [148] (Figure 9a). Modifying DNA by altering its chemical properties has also been shown to achieve membrane-DNA interactions, where the hydrophobicity of the DNA was achieved via alkylation (Figure 9b). One of the most common features of DNA nanopore is to allow the ion conduction through lipid bilayers and showing the gating and voltage-switching behavior. Gopfrich et al. demonstrated such function by employing DNA-based membrane channel with openings that are much smaller than a six-helix bundle (Figure 9d) [149]. Chidchob et al. showcased the flexibility to the programmable design featuring a cubic DNA scaffold with cholesterol anchors to act as a mimicking membrane protein with multiple functions (Figure 9c) [150]. 
One possible application of DNA nanopores in the biomedical field could be to induce cytotoxicity or transport materials through nanopores, such as nucleic acid therapeutics, into the target cells. While most of these DNSs in lipid membranes are designed within synthetic liposomes, the actual cell membrane possesses much more complicated chemical and physical properties than artificial lipid bilayers. Therefore, research on DNA-lipid interactions should also focus on designing nanostructures that interact with native or exogenous cell surfaces to stimulate the cell for intracellular responses and interfere with cellular function. This can also facilitate the delivery of cargos with limited modes of delivery, such as proteins.

Although viral-based vectors can deliver a DNA plasmid that encodes a protein of interest, there can be some adverse side effects, the direct delivery of proteins to modulate cell functions is more straightforward. For example, in the delivery of CRISPR-Cas9, a very effective tool in genome editing, plasmids expressing Cas9 can suffer from a high frequency of off-target effects. The delivery of functional Cas9 has been shown to increase genome modification and specificity compared to DNA transfection [151]. In addition to delivering proteins using lipid nanoparticles, Sun et al. reported a DNA-programmed membrane fusion strategy to deliver proteins into live cells [152]. They employed two single-stranded (ss) DNAs (28 nt) with cholesterol anchors, one at the $3^{\prime}$ cholesterol-functionalized ssDNA (anchor 1 ) and its complementary $5^{\prime}$ cholesterol-functionalized ssDNA (anchor 2 ) to mediate fusion between live cell membranes and artificial liposomes (with a mean diameter of $100 \mathrm{~nm}$, for the composition of the lipids). They demonstrated the delivery of cytochrome C into HeLa and L1210 cells and observed a dramatic decrease in cell viability. Their method bypassed the endosome-lysosome-lysosomal escape pathway with a shorter incubation time of $30 \mathrm{~min}$, suggesting a relatively rapid delivery of protein drugs for therapeutic applications.

Table 4. Designs and structures of DNA nanopores.

\begin{tabular}{|c|c|c|c|c|c|c|}
\hline DNA Nanopore Design & Membrane Anchor & $a^{*}$ & $\mathbf{b}^{*}$ & $c^{*}$ & Notable Feature & Ref. \\
\hline Four-helix bundle & Cholesterol & 0.8 & 11 & 4 & Ion conduction through a lipid bilayer & [149] \\
\hline Six-helix bundle & Cholesterol & 2 & 9 & 3 & $\begin{array}{l}\text { Selective transport of small molecules } \\
\text { with different charge }\end{array}$ & [154] \\
\hline Barrel shape & Cholesterol & 2 & 47 & 26 & $\begin{array}{c}\text { Transport of DNA hairpin and } \\
\text { G-quadruplex }\end{array}$ & [155] \\
\hline Square funnel shape & Cholesterol & $6 \times 6$ & 54 & 19 & The first largest synthetic pore & [156] \\
\hline Wireframe cube & Cholesterol & $7 \times 7$ & 7 & 8 & First open-walled DNA nanopore & [150] \\
\hline Single duplex & Tetraphenylporphyrin & & 5 & 6 & $\begin{array}{l}\text { Ion-channel made from } \\
\text { single DNA duplex }\end{array}$ & [157] \\
\hline Six-helix bundle & Tetraphenylporphyrin & 2 & 14 & 2 & Nanopore with two bifunctional tags & [148] \\
\hline Six-helix bundle & Tetraphenylporphyrin & 2 & 14 & 2 & $\begin{array}{l}\text { Low conductance occurs } \\
\text { at a higher voltage }\end{array}$ & [158] \\
\hline Six-helix bundle & Alkylphosphorothiolates & 2 & 15 & 72 & $\begin{array}{c}\text { Nanopore with modified DNA } \\
\text { hydrophobicity }\end{array}$ & [153] \\
\hline $\begin{array}{l}\text { Six-helix bundle } \\
4 \times 4 \text { double } \\
\text { helix octagon }\end{array}$ & $\begin{array}{l}\text { Alkylphosphorothiolates } \\
\text { Cholesterol }\end{array}$ & $\begin{array}{c}2 \\
35\end{array}$ & $\begin{array}{l}15 \\
10\end{array}$ & $\begin{array}{l}72 \\
32\end{array}$ & $\begin{array}{l}\text { Design Simulation } \\
\text { Transport of large macromolecules } \\
\text { such as folded proteins }\end{array}$ & $\begin{array}{l}{[159]} \\
{[160]}\end{array}$ \\
\hline
\end{tabular}

$\mathrm{a}^{*}$ Pore size (inner diameter or width by design) in $\mathrm{nm}, \mathrm{b}^{*}$ channel length (including transmembrane and extra-membrane domains) in $\mathrm{nm}, \mathrm{c}^{*}$ Number of anchors. 
(a)
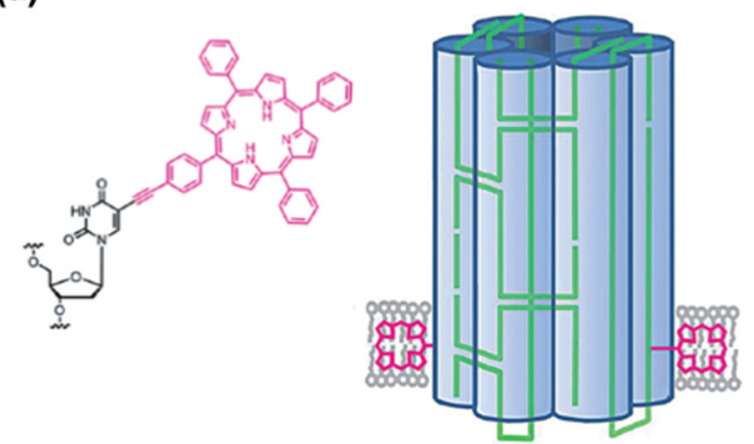

(c)

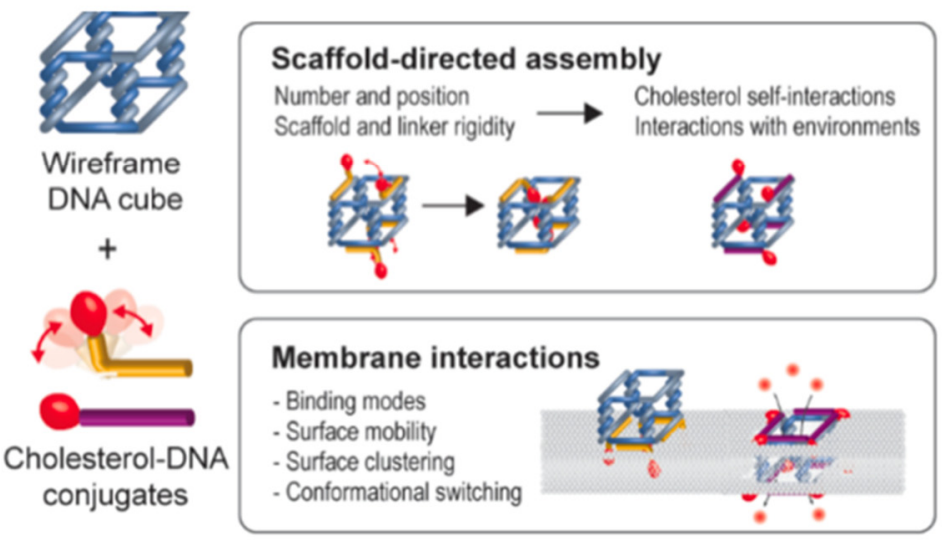

(b)

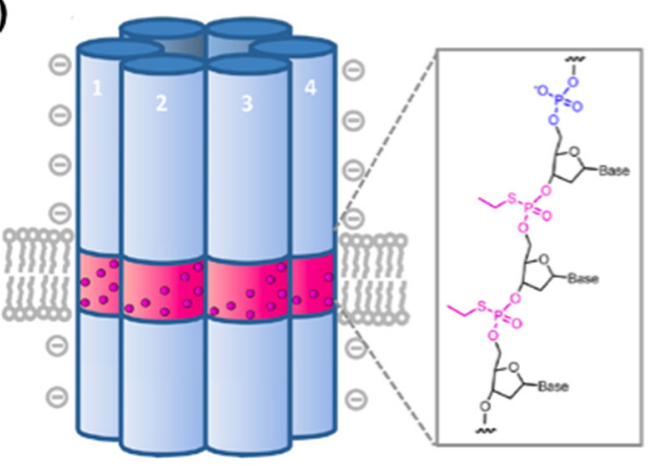

(d)
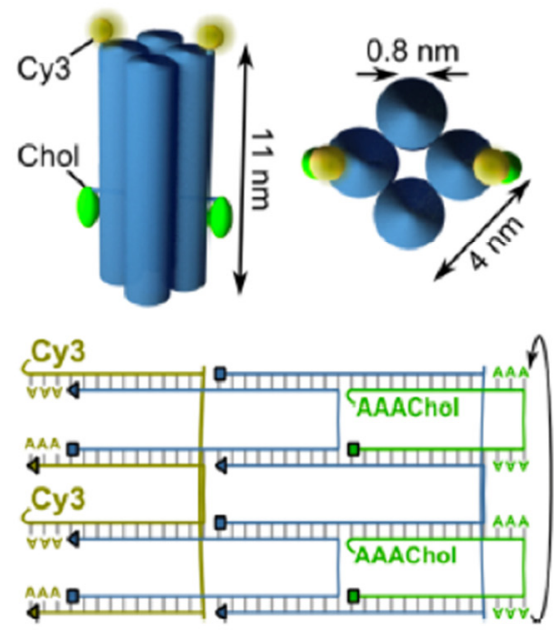

Figure 9. DNA nanostructures interact with the cell membrane. (a) DNA-nanopore carrying porphyrin-based lipid anchors. Deoxyuridine bonded to tetraphenylporphyrin (TPP) through an acetylene linkage at the 5 position of nucleobase (Left) A DNA nanopore composed of six interconnected duplexes, drawn as cylinders. (Green-DNA oligonucleotides, Magenta-Porphyrin tags anchoring the DNA nanopore into the lipid bilayer.) Adapted with permission from [148]. Copyright (c) 2022, The Authors published by Wiley-VCH Verlag GmnH \& Co. KGaA. (b) A DNA nanopore composed of six interconnected duplexes represented as cylinders with an external face featuring a membrane-spanning hydrophobic belt (magenta) where the conventional phosphate of the DNA backbone is substituted with charge-neutral phosphorothioate-ethyl groups. Adapted with permission from [153]. Copyright (C) 2022, American Chemical Society. (c) A DNA cube with cholesterol anchors in lipid membrane mimicking membrane protein. Adapted with permission from [150]. Copyright (C) 2022, American Chemical Society. (d) Schematic side view (top left) and top view (top right) of the DNA-tile structure composed of four interconnected duplexes represented as cylinders. (Green-cholesterol anchors, Yellow-Cy3-tags) and pathways of eight tiles forming the four duplexes and positions of the $\mathrm{Cy} 3$ and cholesterol modifications (Bottom) Adapted with permission from [149]. Copyright (C) 2022, American Chemical Society.

\section{Conclusions}

In this review, we discussed the potential applications of DNSs for biomedicine and therapeutic purposes. DNSs have become a favorable alternative to other drug carriers owing to their biocompatibility, programmability, and biodegradability. While major publications in the field have focused on cancer therapy as a drug or gene carrier for chemotherapy and gene therapy, the use of DNSs has also been explored in the treatment of other diseases such as Alzheimer's disease, Parkinson's disease, and acute kidney disease. Despite the various designs and modifications to DNSs as a drug carrier, most of them have been linked to anti-cancer drugs and ligands that can target molecular 
markers overexpressed on the surface of cancer cells. However, with the advantage of programmability, DNSs can also be applied as vaccine-carrying materials. DNA structures have been found to effectively circumvent drug resistance in several cells. Because of its programmability, a DNA structure can perform multiple tasks as a single structure by executing multiple therapeutic effects and delivering multiple drugs simultaneously. DNA nanorobots can also be programmed with logic-gated molecular designs to achieve the desired output from single, binary, or multiple inputs.

A major concern for the application of DNSs in biomedical applications is the DNA itself. Even though DNA in nature is hereditably biocompatible and may not result in toxicity in the host compared to other nanomaterials, the actual pharmacokinetics of DNSs in the physical body remains to be elucidated. While DNA itself is biodegradable, its properties can change when it self-assembles into DNSs; hence, systemic studies of the behavior of DNSs in the human body should be performed before they can be commercially formulated as therapeutic drugs. Moreover, self-assembled DNSs are designed to assemble in the presence of a high concentration of divalent cations (such as $\mathrm{Mg}^{2+}$ ) which is incompatible with physiological conditions. When attempting to avoid using $\mathrm{Mg}^{2+}$ with monovalent cations such as $\mathrm{Na}^{+}$or $\mathrm{K}^{+}$, which are more commonly present in the body, very high concentrations of such monovalent cations are required to achieve a similar effect and doing so can be counterproductive. Decreasing the concentration of divalent cations close to physiological levels can be deleterious to the stability of DNS before they reach their target cells. Moreover, DNSs are mostly assembled via simple base pairing, and one breakage of such linkages can contribute to the gradual destruction of the entire structure.

Another factor is the vulnerability of DNA to nuclease digestion. Nucleases are abundant in the human body [161] and DNSs will inevitably encounter such enzymes during drug delivery. More structurally compacted DNA origami are generally more resistant to enzyme degradation than linear DNA strands because it takes longer to digest larger DNSs than regular DNA strands. In addition to enzymes, DNS encounters the immune system, which recognizes such structures as foreign materials. To maintain structural integrity and avoid immune recognition, DNSs can be encapsulated in a lipid bilayer to mimic the morphology of viruses. While such modifications are applicable, they will still undermine the ability of DNSs to become a clinical therapeutic agent. In contrast, the design of hybrid systems between DNA structures and other drug vehicles such as polymers, liposomes, and viruses, can focus on the overall efficiency improvement of drug carriers.

Most studies have shown that cells take up DNSs through a limited endocytic pathway. Inside the cell, how DNSs escape endosomes and how much ends up in lysosomes is still unclear. Consequently, the amount of DNS required for a payload to deliver an efficient and adequate effect is unknown, leading to the potential overloading of the drug or payload. To be approved as a clinical drug, in the case of liposomes, the weight-to-weight ratio of drug and lipid should be over $70 \%$ to avoid high lipid concentration in the circulation [162]. Considering this, DNSs of a simple design with less structural complexity and lower molecular weight are more desirable for clinical formulations to reduce the saturation of DNSs in the circulation and minimize unspecific effects. The folding of most origami DNSs depends heavily on the limited number of scaffold species. To address this issue, researchers have focused on developing more economical approaches for the synthesis of scaffolds, such as the application of a polymerase chain reaction [163], rolling circle amplification [164], and the mass production of bacteriophage-derived scaffold molecules [165]. Another concern is the tendency of intercalating drugs to self-associate in aqueous solutions. Drug escape from DNSs could lead to an early release in the circulation, limiting the controlled release of the payload, which is another important factor for using nanocarriers.

DNA nanotechnology is a relatively new field that will inevitably face obstacles and challenges in adapting to practical applications. However, DNSs have prominent features and advantages, such as programmability to carry multiple drugs or multiple types of therapeutics, relatively less toxicity, biocompatibility, and the ability to act as a 
smart therapeutic or intelligent nanorobot. Over the recent decades, DNSs have shown improvements from in vitro to in vivo applications. DNA structures of various sizes and shapes have been tested to carry several payloads, including small-molecule drugs, aptamers, CpG sequences, and antibodies. Several studies have proven that MDR can be overcome by delivering small-molecule drugs loaded in DNSs. More findings suggest an improvement in the specificity and cellular uptake of the payload distributed by DNA nanocarriers. Coupled therapy with multiple payloads or combined therapeutic effects and pathways can result in an overall improved efficiency of fighting against diseases. Several modifications, such as coating DNA origami with proteins, viral capsids, lipids, and polymers, have been made to avoid the adverse effects of nuclease digestion and immune response, as well as to maintain structural integrity. Therefore, with the immense research and current trends in DNA nanotechnology, after the fundamental issues have been addressed, DNA nanocarriers show promise in useful applications for biomedical and biomolecular engineering.

Author Contributions: S.L.A. designed and drafted the manuscript. Y.S. reviewed and edited the manuscript. All authors have read and agreed to the published version of the manuscript.

Funding: This work was partly supported by MEXT/JSPS KAKENHI grant numbers JP19KK0261, JP20K19918, JP20H05970, and JP20H00619 to Y.S.

Conflicts of Interest: The authors declare no conflict of interest.

\section{References}

1. Ghosh, S.; Banerjee, M. A Smart Viral Vector for Targeted Delivery of Hydrophobic Drugs. Sci. Rep. 2021, 11, 7030. [CrossRef] [PubMed]

2. Wang, Y.; Jiang, Y.; Wei, D.; Singh, P.; Yu, Y.; Lee, T.; Zhang, L.; Mandl, H.K.; Piotrowski-Daspit, A.S.; Chen, X.; et al. NanoparticleMediated Convection-Enhanced Delivery of a DNA Intercalator to Gliomas Circumvents Temozolomide Resistance. Nat. Biomed. Eng. 2021, 5, 1048-1058. [CrossRef] [PubMed]

3. Leung, A.K.K.; Hafez, I.M.; Baoukina, S.; Belliveau, N.M.; Zhigaltsev, I.V.; Afshinmanesh, E.; Tieleman, D.P.; Hansen, C.L.; Hope, M.J.; Cullis, P.R. Lipid Nanoparticles Containing SiRNA Synthesized by Microfluidic Mixing Exhibit an Electron-Dense Nanostructured Core. J. Phys. Chem. C 2012, 116, 18440-18450. [CrossRef] [PubMed]

4. $\quad$ Kumar, V.; Qin, J.; Jiang, Y.; Duncan, R.G.; Brigham, B.; Fishman, S.; Nair, J.K.; Akinc, A.; Barros, S.A.; Kasperkovitz, P.V. Shielding of Lipid Nanoparticles for SiRNA Delivery: Impact on Physicochemical Properties, Cytokine Induction, and Efficacy. Mol. Ther. Nucleic Acids 2014, 3, e210. [CrossRef] [PubMed]

5. Fan, Y.; Marioli, M.; Zhang, K. Analytical Characterization of Liposomes and Other Lipid Nanoparticles for Drug Delivery. J. Pharm. Biomed. Anal. 2021, 192, 113642. [CrossRef] [PubMed]

6. Graczyk, A.; Pawlowska, R.; Jedrzejczyk, D.; Chworos, A. Gold Nanoparticles in Conjunction with Nucleic Acids as a Modern Molecular System for Cellular Delivery. Molecules 2020, 25, 204. [CrossRef]

7. Roma-Rodrigues, C.; Pereira, F.; Alves de Matos, A.P.; Fernandes, M.; Baptista, P.V.; Fernandes, A.R. Smuggling Gold Nanoparticles across Cell Types-A New Role for Exosomes in Gene Silencing. Nanomed. Nanotechnol. Biol. Med. 2017, 13, 1389-1398. [CrossRef]

8. Huang, X.; El-Sayed, M.A. Gold Nanoparticles: Optical Properties and Implementations in Cancer Diagnosis and Photothermal Therapy. J. Adv. Res. 2010, 1, 13-28. [CrossRef]

9. Seeman, N.C. Nucleic Acid Junctions and Lattices. J. Theor. Biol. 1982, 99, 237-247. [CrossRef]

10. Winfree, E.; Liu, F.; Wenzler, L.A.; Seeman, N.C. Design and Self-Assembly of Two-Dimensional DNA Crystals. Nature 1998, 394, 539-544. [CrossRef]

11. Rothemund, P.W.K. Folding DNA to Create Nanoscale Shapes and Patterns. Nature 2006, 440, 297-302. [CrossRef] [PubMed]

12. Levy-Nissenbaum, E.; Radovic-Moreno, A.F.; Wang, A.Z.; Langer, R.; Farokhzad, O.C. Nanotechnology and Aptamers: Applications in Drug Delivery. Trends Biotechnol. 2008, 26, 442-449. [CrossRef] [PubMed]

13. Godonoga, M.; Lin, T.-Y.; Oshima, A.; Sumitomo, K.; Tang, M.S.L.; Cheung, Y.-W.; Kinghorn, A.B.; Dirkzwager, R.M.; Zhou, C.; Kuzuya, A.; et al. A DNA Aptamer Recognising a Malaria Protein Biomarker Can Function as Part of a DNA Origami Assembly. Sci. Rep. 2016, 6, 21266. [CrossRef] [PubMed]

14. Arap, W.; Pasqualini, R.; Ruoslahti, E. Cancer Treatment by Targeted Drug Delivery to Tumor Vasculature in a Mouse Model. Science 1998, 279, 377-380. [CrossRef] [PubMed]

15. Cao, M.; Wang, Y.; Zhao, W.; Qi, R.; Han, Y.; Wu, R.; Wang, Y.; Xu, H. Peptide-Induced DNA Condensation into Virus-Mimicking Nanostructures. ACS Appl. Mater. Interfaces 2018, 10, 24349-24360. [CrossRef]

16. Schrama, D.; Reisfeld, R.A.; Becker, J.C. Antibody Targeted Drugs as Cancer Therapeutics. Nat. Rev. Drug. Discov. 2006, 5, 147-159. [CrossRef] 
17. Ranallo, S.; Prévost-Tremblay, C.; Idili, A.; Vallée-Bélisle, A.; Ricci, F. Antibody-Powered Nucleic Acid Release Using a DNA-Based Nanomachine. Nat. Commun. 2017, 8, 15150. [CrossRef]

18. Sudimack, J.; Lee, R.J. Targeted Drug Delivery via the Folate Receptor. Adv. Drug Deliv. Rev. 2000, 41, 147-162. [CrossRef]

19. Ko, S.; Liu, H.; Chen, Y.; Mao, C. DNA Nanotubes as Combinatorial Vehicles for Cellular Delivery. Biomacromolecules 2008, 9 , 3039-3043. [CrossRef]

20. Walsh, A.S.; Yin, H.; Erben, C.M.; Wood, M.J.A.; Turberfield, A.J. DNA Cage Delivery to Mammalian Cells. ACS Nano 2011, 5, 5427-5432. [CrossRef]

21. Hamblin, G.D.; Carneiro, K.M.M.; Fakhoury, J.F.; Bujold, K.E.; Sleiman, H.F. Rolling Circle Amplification-Templated DNA Nanotubes Show Increased Stability and Cell Penetration Ability. J. Am. Chem. Soc. 2012, 134, 2888-2891. [CrossRef] [PubMed]

22. Giljohann, D.A.; Seferos, D.S.; Patel, P.C.; Millstone, J.E.; Rosi, N.L.; Mirkin, C.A. Oligonucleotide Loading Determines Cellular Uptake of DNA-Modified Gold Nanoparticles. Nano Lett. 2007, 7, 3818-3821. [CrossRef] [PubMed]

23. Dix, J.A.; Verkman, A.S. Crowding Effects on Diffusion in Solutions and Cells. Annu. Rev. Biophys. 2008, 37, 247-263. [CrossRef] [PubMed]

24. Liang, L.; Li, J.; Li, Q.; Huang, Q.; Shi, J.; Yan, H.; Fan, C. Single-Particle Tracking and Modulation of Cell Entry Pathways of a Tetrahedral DNA Nanostructure in Live Cells. Angew. Chem. Int. Ed. 2014, 53, 7745-7750. [CrossRef]

25. Vale, R.D.; Milligan, R.A. The Way Things Move: Looking Under the Hood of Molecular Motor Proteins. Science 2000, 288 , 88-95. [CrossRef]

26. Soldati, T.; Schliwa, M. Powering Membrane Traffic in Endocytosis and Recycling. Nat. Rev. Mol. Cell. Biol. 2006, 7, 897-908. [CrossRef]

27. Nichols, B.J.; Lippincott-Schwartz, J. Endocytosis without Clathrin Coats. Trends Cell Biol. 2001, 11, 406-412. [CrossRef]

28. Mikkilä, J.; Eskelinen, A.-P.; Niemelä, E.H.; Linko, V.; Frilander, M.J.; Törmä, P.; Kostiainen, M.A. Virus-Encapsulated DNA Origami Nanostructures for Cellular Delivery. Nano Lett. 2014, 14, 2196-2200. [CrossRef]

29. Perrault, S.D.; Shih, W.M. Virus-Inspired Membrane Encapsulation of DNA Nanostructures To Achieve In Vivo Stability. ACS Nano 2014, 8, 5132-5140. [CrossRef]

30. Sanchez-Rueda, E.G.; Rodriguez-Cristobal, E.; González, C.L.M.; Hernandez-Garcia, A. Protein-Coated DsDNA Nanostars with High Structural Rigidity and High Enzymatic and Thermal Stability. Nanoscale 2019, 11, 18604-18611. [CrossRef]

31. Auvinen, H.; Zhang, H.; Nonappa; Kopilow, A.; Niemelä, E.H.; Nummelin, S.; Correia, A.; Santos, H.A.; Linko, V.; Kostiainen, M.A. Protein Coating of DNA Nanostructures for Enhanced Stability and Immunocompatibility. Adv. Healthc. Mater. 2017, 6, 1700692. [CrossRef] [PubMed]

32. Hernandez-Garcia, A. Strategies to Build Hybrid Protein-DNA Nanostructures. Nanomaterials 2021, 11, 1332. [CrossRef] [PubMed]

33. Hahn, J.; Wickham, S.F.J.; Shih, W.M.; Perrault, S.D. Addressing the Instability of DNA Nanostructures in Tissue Culture. ACS Nano 2014, 8, 8765-8775. [CrossRef]

34. Keum, J.-W.; Bermudez, H. Enhanced Resistance of DNA Nanostructures to Enzymatic Digestion. Chem. Commun. 2009, 45, 7036-7038. [CrossRef]

35. Mei, Q.; Wei, X.; Su, F.; Liu, Y.; Youngbull, C.; Johnson, R.; Lindsay, S.; Yan, H.; Meldrum, D. Stability of DNA Origami Nanoarrays in Cell Lysate. Nano Lett. 2011, 11, 1477-1482. [CrossRef]

36. Castro, C.E.; Kilchherr, F.; Kim, D.-N.; Shiao, E.L.; Wauer, T.; Wortmann, P.; Bathe, M.; Dietz, H. A Primer to Scaffolded DNA Origami. Nat. Methods 2011, 8, 221-229. [CrossRef]

37. Goltry, S.; Hallstrom, N.; Clark, T.; Kuang, W.; Lee, J.; Jorcyk, C.; Knowlton, W.B.; Yurke, B.; Hughes, W.L.; Graugnard, E. DNA Topology Influences Molecular Machine Lifetime in Human Serum. Nanoscale 2015, 7, 10382-10390. [CrossRef]

38. Chandrasekaran, A.R.; Vilcapoma, J.; Dey, P.; Wong-Deyrup, S.W.; Dey, B.K.; Halvorsen, K. Exceptional Nuclease Resistance of Paranemic Crossover (PX) DNA and Crossover-Dependent Biostability of DNA Motifs. J. Am. Chem. Soc. 2020, 142, 6814-6821. [CrossRef]

39. Li, Y.; Song, L.; Wang, B.; He, J.; Li, Y.; Deng, Z.; Mao, C. Universal PH-Responsive and Metal-Ion-Free Self-Assembly of DNA Nanostructures. Angew. Chem. Int. Ed. 2018, 57, 6892-6895. [CrossRef]

40. Cassinelli, V.; Oberleitner, B.; Sobotta, J.; Nickels, P.; Grossi, G.; Kempter, S.; Frischmuth, T.; Liedl, T.; Manetto, A. One-Step Formation of "Chain-Armor"-Stabilized DNA Nanostructures. Angew. Chem. Int. Ed. 2015, 54, 7795-7798. [CrossRef]

41. Gerling, T.; Kube, M.; Kick, B.; Dietz, H. Sequence-Programmable Covalent Bonding of Designed DNA Assemblies. Sci. Adv. 2018, 4, eaau1157. [CrossRef]

42. Lin, C.; Ke, Y.; Li, Z.; Wang, J.H.; Liu, Y.; Yan, H. Mirror Image DNA Nanostructures for Chiral Supramolecular Assemblies. Nano Lett. 2009, 9, 433-436. [CrossRef] [PubMed]

43. Lacroix, A.; Vengut-Climent, E.; de Rochambeau, D.; Sleiman, H.F. Uptake and Fate of Fluorescently Labeled DNA Nanostructures in Cellular Environments: A Cautionary Tale. ACS Cent. Sci. 2019, 5, 882-891. [CrossRef]

44. Conway, J.W.; McLaughlin, C.K.; Castor, K.J.; Sleiman, H. DNA Nanostructure Serum Stability: Greater than the Sum of Its Parts. Chem. Commun. 2013, 49, 1172-1174. [CrossRef] [PubMed]

45. Kim, Y.; Yin, P. Enhancing Biocompatible Stability of DNA Nanostructures Using Dendritic Oligonucleotides and Brick Motifs. Angew. Chem. Int. Ed. 2020, 59, 700-703. [CrossRef] [PubMed]

46. Ahmadi, Y.; Llano, E.D.; Barišić, I. (Poly)Cation-Induced Protection of Conventional and Wireframe DNA Origami Nanostructures. Nanoscale 2018, 10, 7494-7504. [CrossRef] [PubMed] 
47. Ponnuswamy, N.; Bastings, M.M.C.; Nathwani, B.; Ryu, J.H.; Chou, L.Y.T.; Vinther, M.; Li, W.A.; Anastassacos, F.M.; Mooney, D.J.; Shih, W.M. Oligolysine-Based Coating Protects DNA Nanostructures from Low-Salt Denaturation and Nuclease Degradation. Nat. Commun. 2017, 8, 15654. [CrossRef]

48. Chandrasekaran, A.R.; Halvorsen, K. Nuclease Degradation Analysis of DNA Nanostructures Using Gel Electrophoresis. Curr. Protoc. Nucleic Acid Chem. 2020, 82, e115. [CrossRef]

49. Liu, X.; Xu, Y.; Yu, T.; Clifford, C.; Liu, Y.; Yan, H.; Chang, Y. A DNA Nanostructure Platform for Directed Assembly of Synthetic Vaccines. Nano Lett. 2012, 12, 4254-4259. [CrossRef]

50. Liu, J.; Song, L.; Liu, S.; Jiang, Q.; Liu, Q.; Li, N.; Wang, Z.-G.; Ding, B. A DNA-Based Nanocarrier for Efficient Gene Delivery and Combined Cancer Therapy. Nano Lett. 2018, 18, 3328-3334. [CrossRef]

51. Zhang, Q.; Jiang, Q.; Li, N.; Dai, L.; Liu, Q.; Song, L.; Wang, J.; Li, Y.; Tian, J.; Ding, B.; et al. DNA Origami as an In Vivo Drug Delivery Vehicle for Cancer Therapy. ACS Nano 2014, 8, 6633-6643. [CrossRef] [PubMed]

52. Sun, W.; Ji, W.; Hall, J.M.; Hu, Q.; Wang, C.; Beisel, C.L.; Gu, Z. Self-Assembled DNA Nanoclews for the Efficient Delivery of CRISPR-Cas9 for Genome Editing. Angew. Chem. Int. Ed. 2015, 54, 12029-12033. [CrossRef] [PubMed]

53. Zhu, G.; Hu, R.; Zhao, Z.; Chen, Z.; Zhang, X.; Tan, W. Noncanonical Self-Assembly of Multifunctional DNA Nanoflowers for Biomedical Applications. J. Am. Chem. Soc. 2013, 135, 16438-16445. [CrossRef]

54. Bertrand, N.; Wu, J.; Xu, X.; Kamaly, N.; Farokhzad, O.C. Cancer Nanotechnology: The Impact of Passive and Active Targeting in the Era of Modern Cancer Biology. Adv. Drug Deliv. Rev. 2014, 66, 2-25. [CrossRef] [PubMed]

55. Jiang, Q.; Song, C.; Nangreave, J.; Liu, X.; Lin, L.; Qiu, D.; Wang, Z.-G.; Zou, G.; Liang, X.; Yan, H.; et al. DNA Origami as a Carrier for Circumvention of Drug Resistance. J. Am. Chem. Soc. 2012, 134, 13396-13403. [CrossRef]

56. Zhao, Y.-X.; Shaw, A.; Zeng, X.; Benson, E.; Nyström, A.M.; Högberg, B. DNA Origami Delivery System for Cancer Therapy with Tunable Release Properties. ACS Nano 2012, 6, 8684-8691. [CrossRef]

57. Kang, J.H.; Kim, K.-R.; Lee, H.; Ahn, D.-R.; Ko, Y.T. In Vitro and in Vivo Behavior of DNA Tetrahedrons as Tumor-Targeting Nanocarriers for Doxorubicin Delivery. Colloids Surf. B Biointerfaces 2017, 157, 424-431. [CrossRef]

58. Liu, M.; Ma, W.; Li, Q.; Zhao, D.; Shao, X.; Huang, Q.; Hao, L.; Lin, Y. Aptamer-Targeted DNA Nanostructures with Doxorubicin to Treat Protein Tyrosine Kinase 7-Positive Tumours. Cell Prolif. 2019, 52, e12511. [CrossRef]

59. Zhang, G.; Zhang, Z.; Yang, J. DNA Tetrahedron Delivery Enhances Doxorubicin-Induced Apoptosis of HT-29 Colon Cancer Cells. Nanoscale Res. Lett. 2017, 12, 495. [CrossRef]

60. Sun, P.; Zhang, N.; Tang, Y.; Yang, Y.; Chu, X.; Zhao, Y. SL2B Aptamer and Folic Acid Dual-Targeting DNA Nanostructures for Synergic Biological Effect with Chemotherapy to Combat Colorectal Cancer. Int. J. Nanomed. 2017, 12, 2657-2672. [CrossRef]

61. Li, W.; Yang, X.; He, L.; Wang, K.; Wang, Q.; Huang, J.; Liu, J.; Wu, B.; Xu, C. Self-Assembled DNA Nanocentipede as Multivalent Drug Carrier for Targeted Delivery. ACS Appl. Mater. Interfaces 2016, 8, 25733-25740. [CrossRef] [PubMed]

62. Simon, S.M.; Schindler, M. Cell Biological Mechanisms of Multidrug Resistance in Tumors. Proc. Natl. Acad. Sci. USA 1994, 91 , 3497-3504. [CrossRef] [PubMed]

63. Mei, L.; Zhu, G.; Qiu, L.; Wu, C.; Chen, H.; Liang, H.; Cansiz, S.; Lv, Y.; Zhang, X.; Tan, W. Self-Assembled Multifunctional DNA Nanoflowers for the Circumvention of Multidrug Resistance in Targeted Anticancer Drug Delivery. Nano Res. 2015, 8, 3447-3460. [CrossRef] [PubMed]

64. Kim, K.-R.; Kim, D.-R.; Lee, T.; Yhee, J.Y.; Kim, B.-S.; Kwon, I.C.; Ahn, D.-R. Drug Delivery by a Self-Assembled DNA Tetrahedron for Overcoming Drug Resistance in Breast Cancer Cells. Chem. Commun. 2013, 49, 2010-2012. [CrossRef] [PubMed]

65. Halley, P.D.; Lucas, C.R.; McWilliams, E.M.; Webber, M.J.; Patton, R.A.; Kural, C.; Lucas, D.M.; Byrd, J.C.; Castro, C.E Daunorubicin-Loaded DNA Origami Nanostructures Circumvent Drug-Resistance Mechanisms in a Leukemia Model. Small 2016, 12, 308-320. [CrossRef]

66. Ma, W.; Zhan, Y.; Zhang, Y.; Shao, X.; Xie, X.; Mao, C.; Cui, W.; Li, Q.; Shi, J.; Li, J.; et al. An Intelligent DNA Nanorobot with in Vitro Enhanced Protein Lysosomal Degradation of HER. Nano Lett. 2019, 19, 4505-4517. [CrossRef]

67. Zhang, Y.; Jiang, S.; Zhang, D.; Bai, X.M.; Hecht, S.; Chen, S. DNA-Affibody Nanoparticles for Inhibiting Breast Cancer Cells Overexpressing HER. Chem. Commun. 2017, 53, 573-576. [CrossRef]

68. Zhan, Y.; Ma, W.; Zhang, Y.; Mao, C.; Shao, X.; Xie, X.; Wang, F.; Liu, X.; Li, Q.; Lin, Y. DNA-Based Nanomedicine with Targeting and Enhancement of Therapeutic Efficacy of Breast Cancer Cells. ACS Appl. Mater. Interfaces 2019, 11, 15354-15365. [CrossRef]

69. Liu, X.; Wu, L.; Wang, L.; Jiang, W. A Dual-Targeting DNA Tetrahedron Nanocarrier for Breast Cancer Cell Imaging and Drug Delivery. Talanta 2018, 179, 356-363. [CrossRef]

70. Fu, W.; You, C.; Ma, L.; Li, H.; Ju, Y.; Guo, X.; Shi, S.; Zhang, T.; Zhou, R.; Lin, Y. Enhanced Efficacy of Temozolomide Loaded by a Tetrahedral Framework DNA Nanoparticle in the Therapy for Glioblastoma. ACS Appl. Mater. Interfaces 2019, 11, 39525-39533. [CrossRef]

71. Tian, Y.; Huang, Y.; Gao, P.; Chen, T. Nucleus-Targeted DNA Tetrahedron as a Nanocarrier of Metal Complexes for Enhanced Glioma Therapy. Chem. Commun. 2018, 54, 9394-9397. [CrossRef] [PubMed]

72. Yang, J.; Jiang, Q.; He, L.; Zhan, P.; Liu, Q.; Liu, S.; Fu, M.; Liu, J.; Li, C.; Ding, B. Self-Assembled Double-Bundle DNA Tetrahedron for Efficient Antisense Delivery. ACS Appl. Mater. Interfaces 2018, 10, 23693-23699. [CrossRef] [PubMed]

73. Yan, J.; Chen, J.; Zhang, N.; Yang, Y.; Zhu, W.; Li, L.; He, B. Mitochondria-Targeted Tetrahedral DNA Nanostructures for Doxorubicin Delivery and Enhancement of Apoptosis. J. Mater. Chem. B 2020, 8, 492-503. [CrossRef] [PubMed] 
74. Lv, Y.; Hu, R.; Zhu, G.; Zhang, X.; Mei, L.; Liu, Q.; Qiu, L.; Wu, C.; Tan, W. Preparation and Biomedical Applications of Programmable and Multifunctional DNA Nanoflowers. Nat. Protoc. 2015, 10, 1508-1524. [CrossRef]

75. Zhuang, X.; Ma, X.; Xue, X.; Jiang, Q.; Song, L.; Dai, L.; Zhang, C.; Jin, S.; Yang, K.; Ding, B.; et al. A Photosensitizer-Loaded DNA Origami Nanosystem for Photodynamic Therapy. ACS Nano 2016, 10, 3486-3495. [CrossRef]

76. Li, S.; Jiang, Q.; Liu, S.; Zhang, Y.; Tian, Y.; Song, C.; Wang, J.; Zou, Y.; Anderson, G.J.; Han, J.-Y.; et al. A DNA Nanorobot Functions as a Cancer Therapeutic in Response to a Molecular Trigger in Vivo. Nat. Biotechnol. 2018, 36, 258-264. [CrossRef]

77. Chang, M.; Yang, C.-S.; Huang, D.-M. Aptamer-Conjugated DNA Icosahedral Nanoparticles As a Carrier of Doxorubicin for Cancer Therapy. ACS Nano 2011, 5, 6156-6163. [CrossRef]

78. Taghdisi, S.M.; Danesh, N.M.; Ramezani, M.; Lavaee, P.; Jalalian, S.H.; Robati, R.Y.; Abnous, K. Double Targeting and AptamerAssisted Controlled Release Delivery of Epirubicin to Cancer Cells by Aptamers-Based Dendrimer in Vitro and in Vivo. Eur. J. Pharm. Biopharm. 2016, 102, 152-158. [CrossRef]

79. Han, D.; Zhu, G.; Wu, C.; Zhu, Z.; Chen, T.; Zhang, X.; Tan, W. Engineering a Cell-Surface Aptamer Circuit for Targeted and Amplified Photodynamic Cancer Therapy. ACS Nano 2013, 7, 2312-2319. [CrossRef]

80. Zhu, G.; Zheng, J.; Song, E.; Donovan, M.; Zhang, K.; Liu, C.; Tan, W. Self-Assembled, Aptamer-Tethered DNA Nanotrains for Targeted Transport of Molecular Drugs in Cancer Theranostics. Proc. Natl. Acad. Sci. USA 2013, 110, 7998-8003. [CrossRef]

81. Wu, C.; Han, D.; Chen, T.; Peng, L.; Zhu, G.; You, M.; Qiu, L.; Sefah, K.; Zhang, X.; Tan, W. Building a Multifunctional Aptamer-Based DNA Nanoassembly for Targeted Cancer Therapy. J. Am. Chem. Soc. 2013, 135, 18644-18650. [CrossRef] [PubMed]

82. Raniolo, S.; Vindigni, G.; Ottaviani, A.; Unida, V.; Iacovelli, F.; Manetto, A.; Figini, M.; Stella, L.; Desideri, A.; Biocca, S. Selective Targeting and Degradation of Doxorubicin-Loaded Folate-Functionalized DNA Nanocages. Nanomed. Nanotechnol. Biol. Med. 2018, 14, 1181-1190. [CrossRef] [PubMed]

83. Ge, Z.; Guo, L.; Wu, G.; Li, J.; Sun, Y.; Hou, Y.; Shi, J.; Song, S.; Wang, L.; Fan, C.; et al. DNA Origami-Enabled Engineering of Ligand-Drug Conjugates for Targeted Drug Delivery. Small 2020, 16, 1904857. [CrossRef] [PubMed]

84. Ma, W.; Yang, Y.; Zhu, J.; Jia, W.; Zhang, T.; Liu, Z.; Chen, X.; Lin, Y. Biomimetic Nanoerythrosome-Coated Aptamer-DNA Tetrahedron/Maytansine Conjugates: PH-Responsive and Targeted Cytotoxicity for HER2-Positive Breast Cancer. Adv. Mater. 2022. [CrossRef] [PubMed]

85. Li, D.; Li, X.; Yang, F.; Yuan, R.; Xiang, Y. Targeted Delivery of DNA Framework-Encapsulated Native Therapeutic Protein into Cancer Cells. ACS Appl. Mater. Interfaces 2020, 12, 54489-54496. [CrossRef] [PubMed]

86. Wang, S.; Liu, Z.; Tong, Y.; Zhai, Y.; Zhao, X.; Yue, X.; Qiao, Y.; Liu, Y.; Yin, Y.; Xi, R.; et al. Improved Cancer Phototheranostic Efficacy of Hydrophobic IR780 via Parenteral Route by Association with Tetrahedral Nanostructured DNA. J. Control. Release 2021, 330, 483-492. [CrossRef]

87. Chen, X.; Chen, T.; Ren, L.; Chen, G.; Gao, X.; Li, G.; Zhu, X. Triplex DNA Nanoswitch for PH-Sensitive Release of Multiple Cancer Drugs. ACS Nano 2019, 13, 7333-7344. [CrossRef]

88. Krieg, A.M.; Yi, A.-K.; Matson, S.; Waldschmidt, T.J.; Bishop, G.A.; Teasdale, R.; Koretzky, G.A.; Klinman, D.M. CpG Motifs in Bacterial DNA Trigger Direct B-Cell Activation. Nature 1995, 374, 546-549. [CrossRef]

89. Hemmi, H.; Takeuchi, O.; Kawai, T.; Kaisho, T.; Sato, S.; Sanjo, H.; Matsumoto, M.; Hoshino, K.; Wagner, H.; Takeda, K.; et al. A Toll-like Receptor Recognizes Bacterial DNA. Nature 2000, 408, 740-745. [CrossRef]

90. Schmidt, M.; Anton, K.; Nordhaus, C.; Junghans, C.; Wittig, B.; Worm, M. Cytokine and Ig-Production by CG-Containing Sequences with Phosphorodiester Backbone and Dumbbell-Shape. Allergy 2006, 61, 56-63. [CrossRef]

91. Nishikawa, M.; Matono, M.; Rattanakiat, S.; Matsuoka, N.; Takakura, Y. Enhanced Immunostimulatory Activity of Oligodeoxynucleotides by Y-Shape Formation. Immunology 2008, 124, 247-255. [CrossRef] [PubMed]

92. Rattanakiat, S.; Nishikawa, M.; Funabashi, H.; Luo, D.; Takakura, Y. The Assembly of a Short Linear Natural Cytosine-PhosphateGuanine DNA into Dendritic Structures and Its Effect on Immunostimulatory Activity. Biomaterials 2009, 30, 5701-5706. [CrossRef] [PubMed]

93. Li, Y.; Tseng, Y.D.; Kwon, S.Y.; d'Espaux, L.; Bunch, J.S.; McEuen, P.L.; Luo, D. Controlled Assembly of Dendrimer-like DNA. Nat. Mater. 2004, 3, 38-42. [CrossRef]

94. Ouyang, X.; Li, J.; Liu, H.; Zhao, B.; Yan, J.; Ma, Y.; Xiao, S.; Song, S.; Huang, Q.; Chao, J.; et al. Rolling Circle Amplification-Based DNA Origami Nanostructrures for Intracellular Delivery of Immunostimulatory Drugs. Small 2013, 9, 3082-3087. [CrossRef]

95. Zhang, L.; Zhu, G.; Mei, L.; Wu, C.; Qiu, L.; Cui, C.; Liu, Y.; Teng, I.-T.; Tan, W. Self-Assembled DNA Immunonanoflowers as Multivalent CpG Nanoagents. ACS Appl. Mater. Interfaces 2015, 7, 24069-24074. [CrossRef]

96. Mohri, K.; Nishikawa, M.; Takahashi, N.; Shiomi, T.; Matsuoka, N.; Ogawa, K.; Endo, M.; Hidaka, K.; Sugiyama, H.; Takahashi, Y.; et al. Design and Development of Nanosized DNA Assemblies in Polypod-like Structures as Efficient Vehicles for Immunostimulatory CpG Motifs to Immune Cells. ACS Nano 2012, 6, 5931-5940. [CrossRef]

97. Li, J.; Pei, H.; Zhu, B.; Liang, L.; Wei, M.; He, Y.; Chen, N.; Li, D.; Huang, Q.; Fan, C. Self-Assembled Multivalent DNA Nanostructures for Noninvasive Intracellular Delivery of Immunostimulatory CpG Oligonucleotides. ACS Nano 2011, 5, 8783-8789. [CrossRef]

98. Schüller, V.J.; Heidegger, S.; Sandholzer, N.; Nickels, P.C.; Suhartha, N.A.; Endres, S.; Bourquin, C.; Liedl, T. Cellular Immunostimulation by CpG-Sequence-Coated DNA Origami Structures. ACS Nano 2011, 5, 9696-9702. [CrossRef] 
99. Charoenphol, P.; Bermudez, H. Aptamer-Targeted DNA Nanostructures for Therapeutic Delivery. Mol. Pharm. 2014, 11, 1721-1725. [CrossRef]

100. Lee, H.; Lytton-Jean, A.K.R.; Chen, Y.; Love, K.T.; Park, A.I.; Karagiannis, E.D.; Sehgal, A.; Querbes, W.; Zurenko, C.S.; Jayaraman, M.; et al. Molecularly Self-Assembled Nucleic Acid Nanoparticles for Targeted in Vivo SiRNA Delivery. Nat. Nanotechnol. 2012, 7, 389-393. [CrossRef]

101. Kim, K.-R.; Jegal, H.; Kim, J.; Ahn, D.-R. A Self-Assembled DNA Tetrahedron as a Carrier for in Vivo Liver-Specific Delivery of SiRNA. Biomater. Sci. 2020, 8, 586-590. [CrossRef] [PubMed]

102. Xue, H.; Ding, F.; Zhang, J.; Guo, Y.; Gao, X.; Feng, J.; Zhu, X.; Zhang, C. DNA Tetrahedron-Based Nanogels for SiRNA Delivery and Gene Silencing. Chem. Commun. 2019, 55, 4222-4225. [CrossRef] [PubMed]

103. Fu, X.; Chen, T.; Song, Y.; Feng, C.; Chen, H.; Zhang, Q.; Chen, G.; Zhu, X. MRNA Delivery by a PH-Responsive DNA Nano-Hydrogel. Small 2021, 17, e2101224. [CrossRef] [PubMed]

104. Fakhoury, J.J.; McLaughlin, C.K.; Edwardson, T.W.; Conway, J.W.; Sleiman, H.F. Development and Characterization of Gene Silencing DNA Cages. Biomacromolecules 2014, 15, 276-282. [CrossRef] [PubMed]

105. Bujold, K.E.; Hsu, J.C.C.; Sleiman, H.F. Optimized DNA “Nanosuitcases” for Encapsulation and Conditional Release of SiRNA. J. Am. Chem. Soc. 2016, 138, 14030-14038. [CrossRef]

106. Zhang, D.Y.; Seelig, G. Dynamic DNA Nanotechnology Using Strand-Displacement Reactions. Nat. Chem. 2011, 3, 103-113. [CrossRef]

107. Ran, F.A.; Hsu, P.D.; Wright, J.; Agarwala, V.; Scott, D.A.; Zhang, F. Genome Engineering Using the CRISPR-Cas9 System. Nat. Protoc. 2013, 8, 2281-2308. [CrossRef]

108. Liu, J.; Wu, T.; Lu, X.; Wu, X.; Liu, S.; Zhao, S.; Xu, X.; Ding, B. A Self-Assembled Platform Based on Branched DNA for SgRNA/Cas9/Antisense Delivery. J. Am. Chem. Soc. 2019, 141, 19032-19037. [CrossRef]

109. Douglas, S.M.; Bachelet, I.; Church, G.M. A Logic-Gated Nanorobot for Targeted Transport of Molecular Payloads. Science 2012, 335, 831-834. [CrossRef]

110. Douglas, S.M.; Dietz, H.; Liedl, T.; Högberg, B.; Graf, F.; Shih, W.M. Self-Assembly of DNA into Nanoscale Three-Dimensional Shapes. Nature 2009, 459, 414-418. [CrossRef]

111. Hamaguchi, N.; Ellington, A.; Stanton, M. Aptamer Beacons for the Direct Detection of Proteins. Anal. Biochem. 2001, $294,126-131$. [CrossRef] [PubMed]

112. Boniface, J.J.; Rabinowitz, J.D.; Wülfing, C.; Hampl, J.; Reich, Z.; Altman, J.D.; Kantor, R.M.; Beeson, C.; McConnell, H.M.; Davis, M.M. Initiation of Signal Transduction through the T Cell Receptor Requires the Multivalent Engagement of Peptide/MHC Ligands. Immunity 1998, 9, 459-466. [CrossRef]

113. Amir, Y.; Ben-Ishay, E.; Levner, D.; Ittah, S.; Abu-Horowitz, A.; Bachelet, I. Universal Computing by DNA Origami Robots in a Living Animal. Nat. Nanotechnol. 2014, 9, 353-357. [CrossRef] [PubMed]

114. Yang, J.; Jiang, S.; Liu, X.; Pan, L.; Zhang, C. Aptamer-Binding Directed DNA Origami Pattern for Logic Gates. ACS Appl. Mater. Interfaces 2016, 8, 34054-34060. [CrossRef]

115. Liu, F.; Liu, X.; Shi, Q.; Maffeo, C.; Kojima, M.; Dong, L.; Aksimentiev, A.; Huang, Q.; Fukuda, T.; Arai, T. A Tetrahedral DNA Nanorobot with Conformational Change in Response to Molecular Trigger. Nanoscale 2021, 13, 15552-15559. [CrossRef]

116. Li, S.; Jiang, D.; Rosenkrans, Z.T.; Barnhart, T.E.; Ehlerding, E.B.; Ni, D.; Engle, J.W.; Cai, W. Aptamer-Conjugated Framework Nucleic Acids for the Repair of Cerebral Ischemia-Reperfusion Injury. Nano Lett. 2019, 19, 7334-7341. [CrossRef]

117. Zhou, Y.; Yang, Q.; Wang, F.; Zhou, Z.; Xu, J.; Cheng, S.; Cheng, Y. Self-Assembled DNA Nanostructure as a Carrier for Targeted SiRNA Delivery in Glioma Cells. Int. J. Nanomed. 2021, 16, 1805-1817. [CrossRef]

118. Li, F.; Lu, J.; Liu, J.; Liang, C.; Wang, M.; Wang, L.; Li, D.; Yao, H.; Zhang, Q.; Wen, J.; et al. A Water-Soluble Nucleolin Aptamer-Paclitaxel Conjugate for Tumor-Specific Targeting in Ovarian Cancer. Nat. Commun. 2017, 8, 1390. [CrossRef]

119. Bates, P.J.; Reyes-Reyes, E.M.; Malik, M.T.; Murphy, E.M.; O'Toole, M.G.; Trent, J.O. G-Quadruplex Oligonucleotide AS1411 as a Cancer-Targeting Agent: Uses and Mechanisms. Biochim. Biophys. Acta-Gen. Subj. 2017, 1861, 1414-1428. [CrossRef]

120. Shi, S.; Fu, W.; Lin, S.; Tian, T.; Li, S.; Shao, X.; Zhang, Y.; Zhang, T.; Tang, Z.; Zhou, Y.; et al. Targeted and Effective Glioblastoma Therapy via Aptamer-Modified Tetrahedral Framework Nucleic Acid-Paclitaxel Nanoconjugates That Can Pass the Blood Brain Barrier. Nanomed. Nanotechnol. Biol. Med. 2019, 21, 102061. [CrossRef]

121. Xie, X.; Shao, X.; Ma, W.; Zhao, D.; Shi, S.; Li, Q.; Lin, Y. Overcoming Drug-Resistant Lung Cancer by Paclitaxel Loaded Tetrahedral DNA Nanostructures. Nanoscale 2018, 10, 5457-5465. [CrossRef] [PubMed]

122. Cui, W.; Zhan, Y.; Shao, X.; Fu, W.; Xiao, D.; Zhu, J.; Qin, X.; Zhang, T.; Zhang, M.; Zhou, Y.; et al. Neuroprotective and Neurotherapeutic Effects of Tetrahedral Framework Nucleic Acids on Parkinson's Disease in Vitro. ACS Appl. Mater. Interfaces 2019, 11, 32787-32797. [CrossRef] [PubMed]

123. Zhang, Q.; Lin, S.; Wang, L.; Peng, S.; Tian, T.; Li, S.; Xiao, J.; Lin, Y. Tetrahedral Framework Nucleic Acids Act as Antioxidants in Acute Kidney Injury Treatment. Chem. Eng. J. 2021, 413, 127426. [CrossRef]

124. Yao, Y.; Wen, Y.; Li, Y.; Zhu, J.; Tian, T.; Zhang, Q.; Xiao, D.; Gao, Y.; Lin, Y.; Wei, W.; et al. Tetrahedral Framework Nucleic Acids Facilitate Neurorestoration of Facial Nerves by Activating the NGF/PI3K/AKT Pathway. Nanoscale 2021, 13, 15598-15610. [CrossRef]

125. Chen, X.; Xie, Y.; Liu, Z.; Lin, Y. Application of Programmable Tetrahedral Framework Nucleic Acid-Based Nanomaterials in Neurological Disorders: Progress and Prospects. Front. Bioeng. Biotechnol. 2021, 9, 782237. [CrossRef] 
126. Yang, Y.; Zhu, J.; Ma, W.; Zhang, W.; Xie, Y.; Chen, X.; Zhu, J.; Liu, Y.; Qin, X.; Lin, Y. The Remyelination Effect of DNA Framework Nucleic Acids on Demyelinating Diseases. Appl. Mater. Today 2021, 24, 101098. [CrossRef]

127. Liu, N.; Zhang, X.; Li, N.; Zhou, M.; Zhang, T.; Li, S.; Cai, X.; Ji, P.; Lin, Y. Tetrahedral Framework Nucleic Acids Promote Corneal Epithelial Wound Healing in Vitro and in Vivo. Small 2019, 15, 1901907. [CrossRef]

128. Jiang, D.; Ge, Z.; Im, H.-J.; England, C.G.; Ni, D.; Hou, J.; Zhang, L.; Kutyreff, C.J.; Yan, Y.; Liu, Y.; et al. DNA Origami Nanostructures Can Exhibit Preferential Renal Uptake and Alleviate Acute Kidney Injury. Nat. Biomed. Eng. 2018, 2, 865-877. [CrossRef]

129. Chen, Q.; Ding, F.; Zhang, S.; Li, Q.; Liu, X.; Song, H.; Zuo, X.; Fan, C.; Mou, S.; Ge, Z. Sequential Therapy of Acute Kidney Injury with a DNA Nanodevice. Nano Lett. 2021, 21, 4394-4402. [CrossRef]

130. Li, S.; Liu, Y.; Tian, T.; Zhang, T.; Lin, S.; Zhou, M.; Zhang, X.; Lin, Y.; Cai, X. Bioswitchable Delivery of MicroRNA by Framework Nucleic Acids: Application to Bone Regeneration. Small 2021, 17, e2104359. [CrossRef]

131. Qin, X.; Xiao, L.; Li, N.; Hou, C.; Li, W.; Li, J.; Yan, N.; Lin, Y. Tetrahedral Framework Nucleic Acids-Based Delivery of MicroRNA-155 Inhibits Choroidal Neovascularization by Regulating the Polarization of Macrophages. Bioact. Mater. 2021; in press. [CrossRef]

132. Zhang, Y.; Xie, X.; Ma, W.; Zhan, Y.; Mao, C.; Shao, X.; Lin, Y. Multi-Targeted Antisense Oligonucleotide Delivery by a Framework Nucleic Acid for Inhibiting Biofilm Formation and Virulence. Nano-Micro Lett. 2020, 12, 74. [CrossRef] [PubMed]

133. Liu, Y.; Sun, Y.; Li, S.; Liu, M.; Qin, X.; Chen, X.; Lin, Y. Tetrahedral Framework Nucleic Acids Deliver Antimicrobial Peptides with Improved Effects and Less Susceptibility to Bacterial Degradation. Nano Lett. 2020, 20, 3602-3610. [CrossRef] [PubMed]

134. Zhang, T.; Tian, T.; Zhou, R.; Li, S.; Ma, W.; Zhang, Y.; Liu, N.; Shi, S.; Li, Q.; Xie, X.; et al. Design, Fabrication and Applications of Tetrahedral DNA Nanostructure-Based Multifunctional Complexes in Drug Delivery and Biomedical Treatment. Nat. Protoc. 2020, 15, 2728-2757. [CrossRef]

135. Shao, X.; Ma, W.; Xie, X.; Li, Q.; Lin, S.; Zhang, T.; Lin, Y. Neuroprotective Effect of Tetrahedral DNA Nanostructures in a Cell Model of Alzheimer's Disease. ACS Appl. Mater. Interfaces 2018, 10, 23682-23692. [CrossRef]

136. Shao, X.; Cui, W.; Xie, X.; Ma, W.; Zhan, Y.; Lin, Y. Treatment of Alzheimer's Disease with Framework Nucleic Acids. Cell Prolif. 2020, 53, e12787. [CrossRef]

137. Qin, X.; Li, N.; Zhang, M.; Lin, S.; Zhu, J.; Xiao, D.; Cui, W.; Zhang, T.; Lin, Y.; Cai, X. Tetrahedral Framework Nucleic Acids Prevent Retina Ischemia-Reperfusion Injury from Oxidative Stress via Activating the Akt/Nrf2 Pathway. Nanoscale 2019, 11, 20667-20675. [CrossRef]

138. Ma, W.; Zhan, Y.; Zhang, Y.; Xie, X.; Mao, C.; Lin, Y. Enhanced Neural Regeneration with a Concomitant Treatment of Framework Nucleic Acid and Stem Cells in Spinal Cord Injury. ACS Appl. Mater. Interfaces 2020, 12, 2095-2106. [CrossRef]

139. Fu, W.; Ma, L.; Ju, Y.; Xu, J.; Li, H.; Shi, S.; Zhang, T.; Zhou, R.; Zhu, J.; Xu, R.; et al. Therapeutic SiCCR2 Loaded by Tetrahedral Framework DNA Nanorobotics in Therapy for Intracranial Hemorrhage. Adv. Funct. Mater. 2021, 31, 2101435. [CrossRef]

140. Li, J.; Xiao, L.; Yan, N.; Li, Y.; Wang, Y.; Qin, X.; Zhao, D.; Liu, M.; Li, N.; Lin, Y. The Neuroprotective Effect of MicroRNA-22-3p Modified Tetrahedral Framework Nucleic Acids on Damaged Retinal Neurons Via TrkB/BDNF Signaling Pathway. Adv. Funct. Mater. 2021, 31, 2104141. [CrossRef]

141. Cui, W.; Yang, X.; Chen, X.; Xiao, D.; Zhu, J.; Zhang, M.; Qin, X.; Ma, X.; Lin, Y. Treating LRRK2-Related Parkinson's Disease by Inhibiting the MTOR Signaling Pathway to Restore Autophagy. Adv. Funct. Mater. 2021, 31, 2105152. [CrossRef]

142. Kumar, P.; Nagarajan, A.; Uchil, P.D. DNA Transfection Mediated by Cationic Lipid Reagents. Cold Spring Harb. Protoc. 2019, 2019, pdb.prot095414. [CrossRef] [PubMed]

143. Spagnou, S.; Miller, A.D.; Keller, M. Lipidic Carriers of SiRNA: Differences in the Formulation, Cellular Uptake, and Delivery with Plasmid DNA. Biochemistry 2004, 43, 13348-13356. [CrossRef] [PubMed]

144. Ghosh, M.; Ren, G.; Simonsen, J.B.; Ryan, R.O. Cationic Lipid Nanodisks as an SiRNA Delivery Vehicle. Biochem. Cell Biol. 2014, 92, 200-205. [CrossRef] [PubMed]

145. Ewert, K.; Slack, N.L.; Ahmad, A.; Evans, H.M.; Lin, A.J.; Samuel, C.E.; Safinya, C.R. Cationic Lipid-DNA Complexes for Gene Therapy: Understanding the Relationship between Complex Structure and Gene Delivery Pathways at the Molecular Level. Curr. Med. Chem. 2004, 11, 133-149. [CrossRef]

146. Ewert, K.; Ahmad, A.; Evans, H.M.; Safinya, C.R. Cationic Lipid-DNA Complexes for Non-Viral Gene Therapy: Relating Supramolecular Structures to Cellular Pathways. Expert Opin. Biol. Ther. 2005, 5, 33-53. [CrossRef]

147. Sato, Y.; Endo, M.; Morita, M.; Takinoue, M.; Sugiyama, H.; Murata, S.; Nomura, S.M.; Suzuki, Y. Environment-Dependent Self-Assembly of DNA Origami Lattices on Phase-Separated Lipid Membranes. Adv. Mater. Interfaces 2018, 5, 1800437. [CrossRef]

148. Burns, J.R.; Göpfrich, K.; Wood, J.W.; Thacker, V.V.; Stulz, E.; Keyser, U.F.; Howorka, S. Lipid-Bilayer-Spanning DNA Nanopores with a Bifunctional Porphyrin Anchor. Angew. Chem. Int. Ed. 2013, 52, 12069-12072. [CrossRef]

149. Göpfrich, K.; Zettl, T.; Meijering, A.E.C.; Hernández-Ainsa, S.; Kocabey, S.; Liedl, T.; Keyser, U.F. DNA-Tile Structures Induce Ionic Currents through Lipid Membranes. Nano Lett. 2015, 15, 3134-3138. [CrossRef]

150. Chidchob, P.; Offenbartl-Stiegert, D.; McCarthy, D.; Luo, X.; Li, J.; Howorka, S.; Sleiman, H.F. Spatial Presentation of Cholesterol Units on a DNA Cube as a Determinant of Membrane Protein-Mimicking Functions. J. Am. Chem. Soc. 2019, 141, 1100-1108. [CrossRef] 
151. Wang, M.; Zuris, J.A.; Meng, F.; Rees, H.; Sun, S.; Deng, P.; Han, Y.; Gao, X.; Pouli, D.; Wu, Q.; et al. Efficient Delivery of Genome-Editing Proteins Using Bioreducible Lipid Nanoparticles. Proc. Natl. Acad. Sci. USA 2016, 113, 2868-2873. [CrossRef] [PubMed]

152. Sun, L.; Gao, Y.; Wang, Y.; Wei, Q.; Shi, J.; Chen, N.; Li, D.; Fan, C. Guiding Protein Delivery into Live Cells Using DNAProgrammed Membrane Fusion. Chem. Sci. 2018, 9, 5967-5975. [CrossRef] [PubMed]

153. Burns, J.R.; Stulz, E.; Howorka, S. Self-Assembled DNA Nanopores That Span Lipid Bilayers. Nano Lett. 2013, 13, 2351-2356. [CrossRef] [PubMed]

154. Burns, J.R.; Seifert, A.; Fertig, N.; Howorka, S. A Biomimetic DNA-Based Channel for the Ligand-Controlled Transport of Charged Molecular Cargo across a Biological Membrane. Nat. Nanotechnol. 2016, 11, 152-156. [CrossRef]

155. Langecker, M.; Arnaut, V.; Martin, T.G.; List, J.; Renner, S.; Mayer, M.; Dietz, H.; Simmel, F.C. Synthetic Lipid Membrane Channels Formed by Designed DNA Nanostructures. Science 2012, 338, 6109. [CrossRef]

156. Göpfrich, K.; Li, C.-Y.; Ricci, M.; Bhamidimarri, S.P.; Yoo, J.; Gyenes, B.; Ohmann, A.; Winterhalter, M.; Aksimentiev, A.; Keyser, U.F. Large-Conductance Transmembrane Porin Made from DNA Origami. ACS Nano 2016, 10, 8207-8214. [CrossRef]

157. Göpfrich, K.; Li, C.-Y.; Mames, I.; Bhamidimarri, S.P.; Ricci, M.; Yoo, J.; Mames, A.; Ohmann, A.; Winterhalter, M.; Stulz, E.; et al. Ion Channels Made from a Single Membrane-Spanning DNA Duplex. Nano Lett. 2016, 16, 4665-4669. [CrossRef]

158. Seifert, A.; Göpfrich, K.; Burns, J.R.; Fertig, N.; Keyser, U.F.; Howorka, S. Bilayer-Spanning DNA Nanopores with VoltageSwitching between Open and Closed State. ACS Nano 2015, 9, 1117-1126. [CrossRef]

159. Maingi, V.; Burns, J.R.; Uusitalo, J.J.; Howorka, S.; Marrink, S.J.; Sansom, M.S.P. Stability and Dynamics of Membrane-Spanning DNA Nanopores. Nat. Commun. 2017, 8, 14784. [CrossRef]

160. Fragasso, A.; De Franceschi, N.; Stömmer, P.; van der Sluis, E.O.; Dietz, H.; Dekker, C. Reconstitution of Ultrawide DNA Origami Pores in Liposomes for Transmembrane Transport of Macromolecules. ACS Nano 2021, 15, 12768-12779. [CrossRef]

161. Kishi, K.; Yasuda, T.; Ikehara, Y.; Sawazaki, K.; Sato, W.; Iida, R. Human Serum Deoxyribonuclease I (DNase I) Polymorphism: Pattern Similarities among Isozymes from Serum, Urine, Kidney, Liver, and Pancreas. Am. J. Hum. Genet. 1990, 47, 121-126. [PubMed]

162. Haran, G.; Cohen, R.; Bar, L.K.; Barenholz, Y. Transmembrane Ammonium Sulfate Gradients in Liposomes Produce Efficient and Stable Entrapment of Amphipathic Weak Bases. Biochim. Biophys. Acta Biomembr. 1993, 1151, 201-215. [CrossRef]

163. Pound, E.; Ashton, J.R.; Becerril, H.A.; Woolley, A.T. Polymerase Chain Reaction Based Scaffold Preparation for the Production of Thin, Branched DNA Origami Nanostructures of Arbitrary Sizes. Nano Lett. 2009, 9, 4302-4305. [CrossRef] [PubMed]

164. Xu, M.; Zhang, C.; Zhang, C.; Zhao, Y.; Qi, Z.; Fan, C.; Chao, J.; Wei, B. DNA Origami Nanostructures with Scaffolds Obtained from Rolling Circle Amplification. ACS Mater. Lett. 2020, 2, 1322-1327. [CrossRef]

165. Praetorius, F.; Kick, B.; Behler, K.L.; Honemann, M.N.; Weuster-Botz, D.; Dietz, H. Biotechnological Mass Production of DNA Origami. Nature 2017, 552, 84-87. [CrossRef] 